NRRI 96-09

\title{
INFORMATION RISK IN EMERGING UTILITY MARKETS: THE ROLE OF COMMISSION-SPONSORED AUDITS
}

David W. Wirick

Associate Director
Raymond W. Lawton, Ph.D.

Associate Director

Robert E. Burns, Esq.

Senior Research Specialist

with

Sangjin Lee

Graduate Research Associate

THE NATIONAL REGULATORY RESEARCH INSTITUTE

The Ohio State University

1080 Carmack Road

Columbus, Ohio 43210

(614) 292-9404

March 1996

This report was prepared by The National Regulatory Research Institute (NRRI) with funding provided by participating member commissions of the National Association of Regulatory Utility Commissioners (NARUC). The views and opinions of the authors do not necessarily state or reflect the views, opinions, or policies of the NRRI. the NARUC, or their contributors.

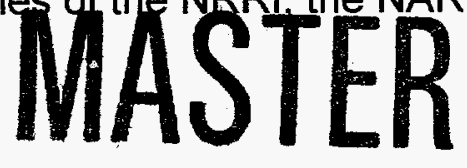




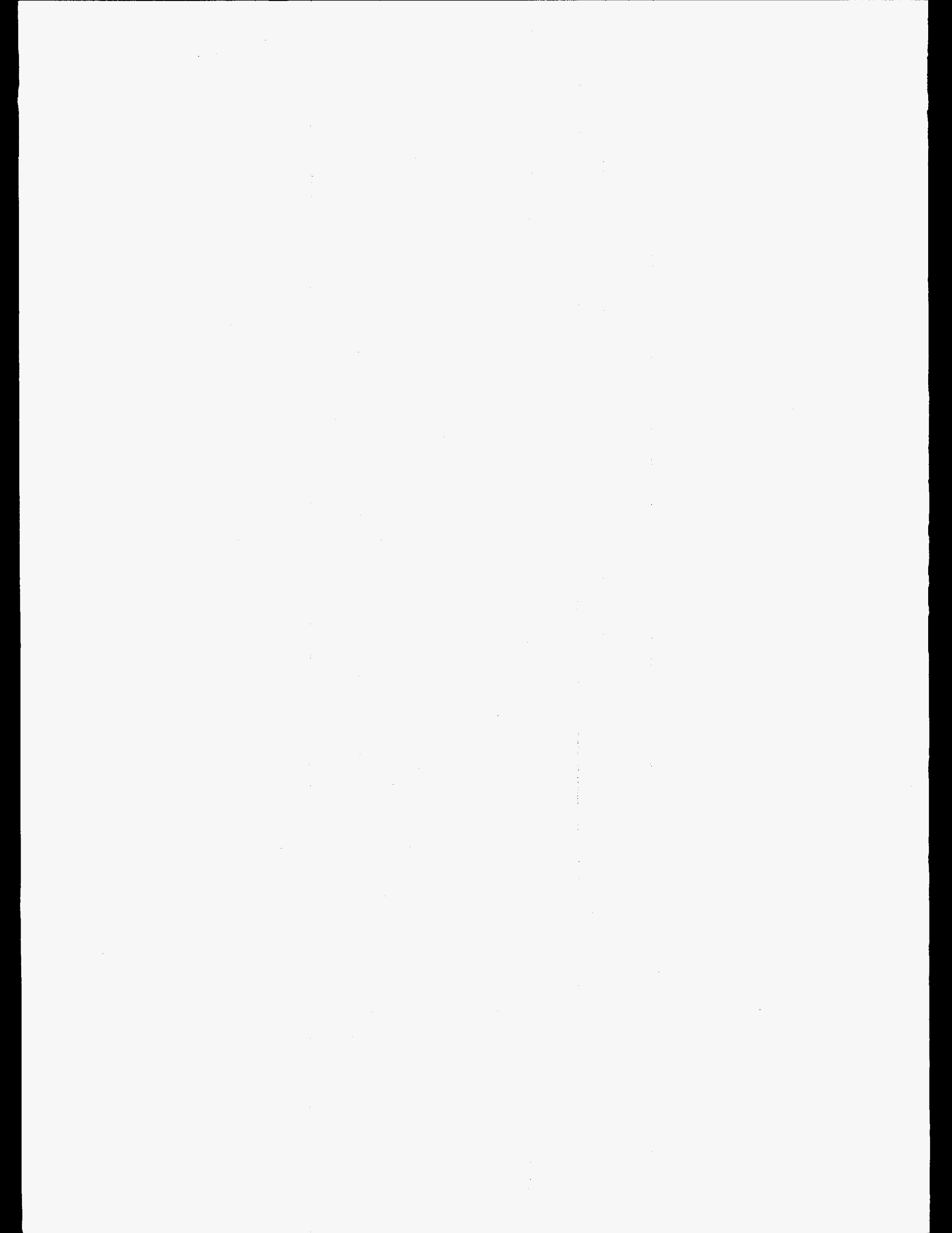




\section{DISCLAIMER}

This report was prepared as an account of work sponsored by an agency of the United States Government. Neither the United States Government nor any agency thereof, nor any of their employees, make any warranty, express or implied, or assumes any legal liability or responsibility for the accuracy, completeness, or usefulness of any information, apparatus, product, or process disclased, or represents that its use would not infringe privately owned rights. Reference herein to any specific commercial product, process, or service by trade name, trademark, manufacturer, or otherwise does not necessarily constitute or imply its endorsement, recommendation, or favoring by the United States Government or any agency thereof. The views and opinions of authors expressed herein do not necessarily state or reflect those of the United States Government or any agency thereof. 


\section{DISCLAMMER}

Portions of this document may be illegible in electronic image products. Images are produced from the best available original document. 


\section{EXECUTIVE SUMMARY}

Regulatory commissions in most states and federal agencies have extensively employed audits as a regulatory tool in support of their traditional authority to set rates and assure the quality of utility service. As the regulatory environment changes, however, questions are being raised about the continued validity of audits performed by commission staffs or audits conducted by contractors employed by commissions.

As audit practice has developed and changed for other industries and segments of the economy, it has also evolved for regulated utilities. In the past, audits were often connected with rate cases. As the frequency of rate cases decreased, the focus of commission-sponsored audits shifted to monitoring, reporting, compliance auditing, analytical reviews, and management performance. Commissions began to supplement their financial audits with management audits following the discovery of huge cost overruns in nuclear power plants in the early 1980s. Today, management audits cover a wide array of issues including staffing patterns, wage and salary scales, investment policies, and purchasing and payment arrangements with affiliated interests.

Audits can be categorized in several ways. There are financial audits, compliance audits, and operational or management audits. Performance audits, a subset of operational and management audits, include economy and efficiency and program audits. Commission-sponsored audits can also be characterized as verification audits, in which information provided to the commission is verified for its accuracy, and discovery audits, which attempt to identify new information of interest to the commission. In addition to their verification and discovery functions, audits also perform an explicit and implicit compliance function as they help induce utilities to conform to commission mandates.

The primary purpose of an audit is to reduce information risk. Information risk, in a regulatory context, is the risk that a commission might make a wrong decision because of reliance on faulty information. In the future, if the decision-making role of state commissions is minimized, their need for information and concern with information 
risk will also be minimized. The level of information risk is different for each type of information collected, and the level of risk determines the need for audits or other methods for mitigating information risk.

Not all information has embedded in it the same level of information risk. Four factors (the magnitude of the decisions based on the information, the verifiability of the information, the materiality of the information, and the relationship between the commission and the information source) contribute to the level of information risk. As the magnitude of the decisions based on the information increases, the relative level of information risk increases. If information is difficult to verify, the risk increases. If the information is material (and there is both a quantitative and qualitative component to materiality), the risk increases. And if the relationship between the commission and the source of the information is uncertain or strained, the information risk also increases.

A commission-sponsored audit is not required, however, simply because risk exists. There are many available techniques for mitigating information risk. They include the requirement that the utility submit data in standardized formats, the requirement that the utility's records be audited by an independent auditor, the use of commission-sponsored audits, and independent gathering of the information by the commission itself.

Federal regulatory bodies in fields other than public utility regulation have employed a mix of risk-mitigation options to support their missions. The Securities and Exchange Commission primarily relies on the establishment of detailed accounting guidelines and certification of the accuracy of submitted information by independent accountants. The U.S. Department of Transportation requires certification by independent auditors and employs ten data bases to review submitted data for irregularities. The Federal Deposit Insurance Corporation uses an aggressive system of field audits and checks on data submitted. The Environmental Protection Agency performs audits and financial reviews.

As commissions attempt to determine the right mix of risk-mitigation techniques to apply to each element of necessary information, we suggest the application of a five- 
step process: (1) identification of decision-making requirements, (2) identification of information necessary to support decisions, (3) evaluation of information risk, (4) identification of options to mitigate risk, and, ultimately, (5) cost-benefit analysis of the applicable methods for mitigating information risk.

To develop an insight on future commission decision-making requirements, the NRRI employed a two-part exercise: (1) extrapolation from the results of the NARUC/NRRI Commissioners Summit and (2) a facilitated discussion with senior staff members of the Public Utilities Commission of Ohio. The first provided a macro view of decision and information needs; the second provided a view of the hands-on needs of a state commission.

Though the results were not identical, there was a high degree of correlation between the two assessments of information needs. Both identified information needs for serving that segment of the utility market that will not immediately reap the full benefits of competition, for making the transition to more competitive markets, and for supporting commissions as they operate in those new environments. Five general categories of necessary information were identified: market information; quality-ofservice and customer satisfaction information, which includes the identification of performance standards; utility financial information; social cost information; and affiliate transaction information.

As commissions attempt to mitigate the risk inherent in this necessary information, their goal should be to reasonably mitigate information risk using the lowest cost alternative. Put another way, commissions should invest in risk-mitigating techniques until the marginal cost of the effort to mitigate risk exceeds the benefit. Cost-benefit analysis is a technique that allows for a comparison of alternatives.

The types of information of most importance to future commission decision making in competitive or partially competitive environments will likely be quality-ofservice information and market information. Those types of information cannot satisfactorily be provided by the utilities and will be the hardest to gather. Because 
these types of information contain the highest risk, commissions should dedicate the most resources to mitigating their risk. Though management audits could be employed to evaluate utility efforts to collect customer information, insure utility compliance with service and safety requirements, and resolve consumer complaints, the use of traditional audits may not be the best technique for mitigating risk for quality-of-service information and may only be partly applicable for mitigating the risk of market information. Enough information risk may still attend affiliate transaction information and utility financial information to justify the application of traditional commissionsponsored audits.

It is clear that commissions will continue to make decisions and will continue to need information to support those decisions. It appears likely, however, that the information needed by commissions will change. There will still be a need for traditional utility cost and financial information in those markets where the role of the commission is protection of core customers. In transition markets, commissions will need both traditional information and new sources of information that will assess the impact of utility actions on markets and consumers. To generate the new information necessary for regulating competitive markets, commissions will need to enhance their skills in market analysis and survey research to identify consumer preferences and satisfaction with utility services. Some commissions have begun to make use of existing staff expertise in these areas.

Unfortunately, most of the information commissions will need is the same information that utilities and their competitors are most likely to consider confidential or proprietary. In many cases, the utility has a legitimate concern that competitors might use the evidentiary process to discover information that harms the utility's competitive position. Commissions and their staff must be concerned about procedural due process, open records laws, and the claim of confidentiality, sometimes where none actually exists. There are a number of policy options available to commissions to reduce the problems associated with confidential material or claims of confidentiality. For example, they can limit burdensome requests for information, recognize the 
potential for misuse of information for anti-competitive purposes, make use of protective orders, and only release aggregated information.

Audits are powerful tools for reducing information risk, and it is likely that there will continue to be a role for commission-sponsored audits in traditional markets, transition markets, and, to some extent, in more competitive markets. As utilities make the transition to more competitive markets, however, the role of audits (though not necessarily the role of staff currently performing audits) may shrink as commissions apply different methods of regulation and employ new sources of information to support those methods. No matter which options commissions apply to mitigate information risk, they must retain the authority to conduct audits when necessary. 



\section{TABLE OF CONTENTS}

Page

FOREWORD $\ldots \ldots \ldots \ldots \ldots \ldots \ldots \ldots \ldots \ldots \ldots \ldots \ldots \ldots \ldots$

ACKNOWLEDGMENTS $\ldots \ldots \ldots \ldots \ldots \ldots \ldots \ldots \ldots \ldots \ldots$ xii

\section{CHAPTER}

1 The Role of Audits in Public Utility Regulation . . . . . . . . . . . .

The Use of Audits for Business Organizations . . . . . . . . . . 4

Types of Audits . . . . . . . . . . . . . . . . . . . 8

The Relationship of Audits to Risks . . . . . . . . . . . 11

2 Identifying and Mitigating Information Risk $\ldots \ldots \ldots \ldots \ldots$

The Characteristics of Risky Information . . . . . . . . . . . . 15

Methods for Reducing Information Risk . . . . . . . . . . . 19

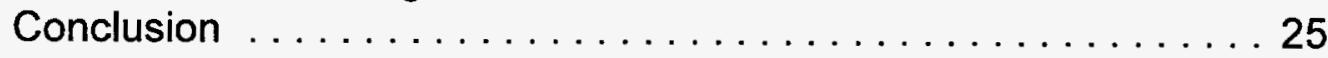

3 Future Commission Decisions and Information Needs . . . . . . . . 27

The NARUC/NRRI Commissioners Summit . . . . . . . . . . . . . 29

Assessment by Staff of the Public Utilities Commission of Ohio . . 33

Conclusions ........................ 39

4 Cost-Benefit Evaluation of Methods to Mitigate Information Risk . . . . 43

The Evaluation Model . . . . . . . . . . . . . . . . . 43

Evaluation of Strategies for Application to

Commission Information Needs . . . . . . . . . . . . . 51

5 Summary and Conclusions . . . . . . . . . . . . . . . . 59

The Changing Information Needs of State Commissions . . . . . . 59

The Use of Audits . . . . . . . . . . . . . . . . . . . . . . 61

Commission Access to Proprietary Information . . . . . . . . .66 63

Maintenance of Audit Authority . . . . . . . . . . . . . 66

Conclusion .......................67 



\section{FOREWORD}

As public utilities and regulators begin to define their new relationships under various forms of regulation, some have questioned the continuing need for audits of utilities by commission staff or by contractors hired by commissions.

This study evaluates the role of commission-sponsored audits by examining their core purpose--the reduction of information risk. It identifies five generic types of information that will be needed by commissions in the future and describes a costbenefit analysis for identifying the appropriate method for mitigating information risk for state regulatory commissions. Importantly, it posits that as the role of commissions change, their information needs, the means they use to gather information, and the methods they employ to reduce information risk will change also.

Douglas N. Jones

Director, NRRI

Columbus, Ohio

February 1996 


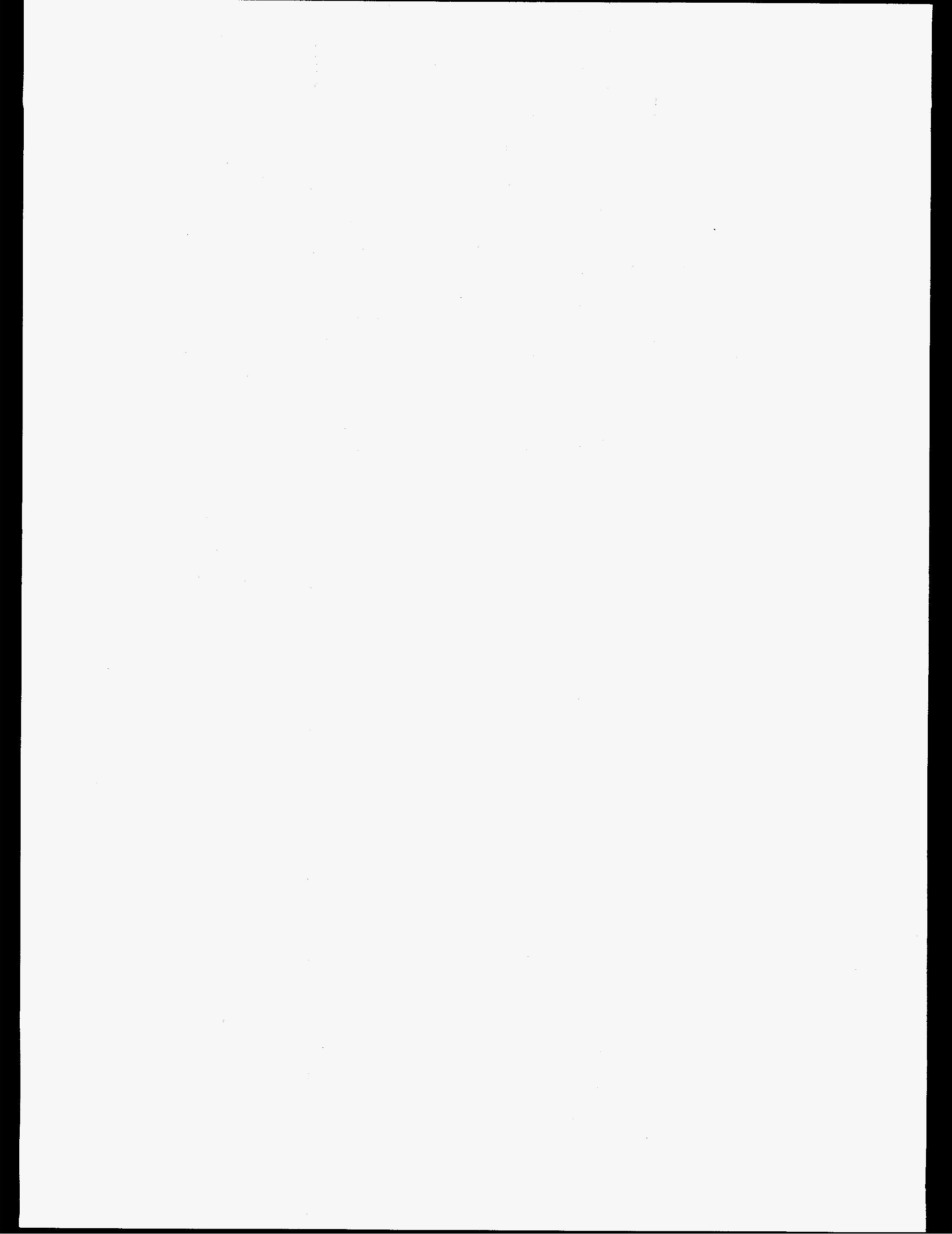




\title{
ACKNOWLEDGMENTS
}

The authors are indebted to many individuals for their support and assistance during the preparation of this report. Wendy Windle and Rosemary Wade assisted with the preparation of tables and figures. Jacquie Shepherd prepared the final copy. Bob Graniere helped Dave Wirick fine tune the economic analysis.

The authors are also indebted to those regulatory commission staff who agreed to review drafts of the report. They include:

\author{
Janice Garrison of the FERC \\ Ken Ackerman of the FCC \\ Tom Ferris of the Wisconsin Public Service Commission \\ Todd Carden of the West Virginia Public Service Commission \\ Bill Meyer of the Missouri Public Service Commission \\ Don Judisch of the lowa Utilities Board \\ Donna Martin of the Illinois Commerce Commission \\ Patti Daniel of the Florida Public Service Commission \\ Lisa Harvey of the Florida Public Service Commission \\ Deborah Bernsen of the Missouri Public Service Commission \\ Jerry Wissman of the Ohio Public Service Commission \\ Dorman Davis of the Mississippi Public Service Commission
}

The authors would also like to express their thanks to the members of the Ohio Public Utilities Commission staff who contributed their expertise during a structured exercise to identify commission information needs. Their names are cited in a footnote to the text.

And a special acknowledgment is necessary for Commissioner Terry Deason of the Florida Public Service Commission and the members of the NARUC Staff Subcommittee on Accounts for their early support of this project and encouragement to examine this difficult issue. 


\section{CHAPTER 1}

\section{THE ROLE OF AUDITS IN PUBLIC UTILITY REGULATION}

As state and federal regulatory commissions exercise their traditional authority to set rates and assure the quality of utility service, they extensively employ audits of jurisdictional public utilities as a regulatory tool. According to data collected by the National Association of Regulatory Utility Commissioners (NARUC), regulated utilities are audited by the staffs of most of the regulatory commissions (forty-nine of fifty-three state-level regulatory commissions), and most commissions (thirty-nine) have the authority to require a periodic audit of jurisdictional utilities by independent accountants. ${ }^{1}$ The Federal Communications Commission (FCC) requires annual audits of certain carriers' cost allocation procedures and conducts special examinations of accounts for specific purposes. ${ }^{2}$ The Federal Energy Regulatory Commission (FERC) requires annual audits by independent accountants for public utilities, and its staff audits regulated utilities. ${ }^{3}$. The Securities and Exchange Commission (SEC) currently has audit authority for subsidiary and mutual service companies, exempt wholesale generators, and foreign utility companies owned by registered holding companies under the Public Utility Holding Company Act of 1935 (PUHCA). In a number of cases, the audits of utilities whose operations cross jurisdictions have been coordinated between the regulatory agencies through NARUC. ${ }^{4}$

${ }^{1}$ NARUC, Utility Regulatory Policy in the United States and Canada: Compilation 1994-95 (Washington, DC: NARUC, 1995), 61-62.

2 Ibid.

${ }^{3}$ Ibid.

${ }^{4}$ Since 1985, the SEC has invited state commissions with jurisdiction over utility subsidiaries of registered holding companies to participate in SEC audits. 
In addition, many commissions conduct or contract for management audits or studies of utility operating performance, structure, objectives, or efficiency. ${ }^{5}$ Within the last five years, approximately 275 of these management audits of utilities were conducted. They covered such varied topics as utility fuel procurement, demand-side management, repair and maintenance practices, affiliate transactions, capital additions, and executive succession planning. ${ }^{6}$

Clearly, audits of utilities by commission staff or contractors employed by commissions are frequently used regulatory tools. (In this report, audits performed by commission staffs and audits conducted

But in the current environment of public utility regulation, the role of commission-sponsored audits of utilities has been called into question. by contractors employed by commissions will be referred to as "commissionsponsored audits.") But in the current environment of public utility regulation, an environment dominated by change, by emerging and actual competition, and by

forms of regulation that differ from traditional ratebase/rate-of-return regulation (RBROR), the role of commission-sponsored audits of utilities has been called into question.

Under traditional RBROR, the rationale for using an audit as a regulatory tool was relatively straightforward. Investigation of the documentation and prudence of costs incurred by a utility could result in audit findings that reduced ratebase or disallowed operating costs. As examples, audit findings under RBROR that revealed excessive executive salaries, unjustified affiliate transaction charges, imprudent investments, questionable treatment of political or charitable contributions, and "gold-

${ }^{5}$ Throughout this report, no attempt will be made to distinguish between audits performed directly by the staffs of the regulatory commissions and audits performed by consultants hired by the commissions. Both will be referred to generically as "commission-sponsored" audits.

${ }^{6}$ NARUC, Utility Regulatory Policy in the United States and Canada, 70-77. 
plating" would generally result in commission actions that reduced ratebase or disallowed operating costs.

In a price cap or performance-based regulation environment, the rationale for using audits as a regulatory tool may not be as clear cut because regulatory commissions are less concerned about costs. Under a pure price cap model, a commission would not necessarily take corrective action based upon audit findings because of the expectation that if a utility chose to act inefficiently, it would suffer because it would earn less.

Today, some wonder whether the information requirements for effective regulation have changed to such an extent that audits are inappropriately targeted or even unnecessary. ${ }^{7}$ It is argued that in more competitive environments and under relaxed methods of regulation, utility operations that formerly were examined by auditors are now beyond the reach and the concern of regulators. Some express concern that proprietary information necessary

Today, some wonder whether the information requirements for effective regulation have changed to such an extent that audits are inappropriately targeted or even unnecessary.

for effective competition with rival utilities will be compromised by commissionsponsored audits.

This report seeks to answer some of those questions and to evaluate the role of commission-sponsored audits of utilities under emerging forms of regulation. Because the need for audits is conditioned by the types of information necessary for effective regulation, the report seeks to identify the decisions commissions are likely to undertake in the future and the information they will need to support those decisions. It

${ }^{7}$ In a survey of the impact of various forms of regulation on auditing conducted by the Florida Public Service Commission, twenty-six respondents from state commissions felt that regulatory audits were still necessary under non-cost based regulation. One said that audits were not necessary. Two were unsure. 
attempts to establish a framework for the choice of risk-mitigation option driven by the level of information risk and a cost-benefit analysis of methods of mitigating information risk. It also examines other agencies, particularly those that have regulatory authority over partially deregulated industries, to determine whether their methods for ensuring the accuracy and adequacy of information are applicable to state and federal regulatory commissions. Finally, this report briefly examines a specific and thorny issue related to commission-sponsored audits--the treatment of proprietary information.

The remainder of this chapter discusses the growth and development of audits as a tool for the evaluation of financial information in general and in the regulation of the public utilities in specific; the types and purposes of audits; and the relationship between audits and information risk, which is the criterion by which the need for an audit or audit program can be evaluated.

\section{The Use of Audits for Business Organizations}

Simple economies prior to the industrial revolution were dominated by owneroperated firms, and there was little need for audits. Managers were on site and third parties were not often involved. But when firms grew larger and owners hired professional managers, the owners needed assurance that they were not being defrauded by their managers. As firms grew, bankers became involved and they, too, needed assurance of the accuracy of financial statements. As a result, the primary focus of audits in this early period was the detection of fraud and reporting errors. ${ }^{8}$

In the first half of the twentieth century, the number of outside investors in firms increased, and with that increase, auditing shifted its emphasis toward insuring that financial statements issued to the public gave a full and fair description of the financial condition of the firm. Auditors also became responsible to government agencies and the stock exchanges that represented the new investors. With this new emphasis on

\footnotetext{
${ }^{8}$ Kurt Pany and O. Ray Whittington, Auditing (Burr Ridge, Illinois: Richard D. Irwin, Inc., 1994), 9.
} 
the accuracy of financial statements as opposed to the detection of fraud and errors, auditors developed techniques of sampling that gave them adequate assurance of the accuracy of financial statements without the need to examine each transaction. They also began to consider the internal controls of the firm with the knowledge that effective internal controls increased the likelihood of the accuracy of the financial statements. ${ }^{9}$

With the financial collapse that signaled the start of the Great Depression, the Congress took an interest in the communication of accurate financial information to the public and became involved in the establishment of accounting standards for private firms. In 1934, Congress established the SEC and gave it the authority to set standards for financial reporting.

However, the SEC opted to delegate the establishment of accounting standards to the accounting community. By announcing that it would regard statements as misleading if they were prepared "in accordance with accounting standards for which there is no substantial authoritative support," ${ }^{10}$ the SEC allowed the accounting community to begin to form the institutions that establish U.S. accounting standards. Even today, the SEC's principal approach to insuring the accuracy of financial statements is to monitor the establishment of effective accounting standards by the accounting community and require the certification by professional accountants that those standards have been met. ${ }^{11}$

${ }^{9}$ Ibid.

${ }^{10}$ Securities and Exchange Commission, "Release No. 4, April 25, 1938, Administrative Policy on Financial Statements," as cited in Subcommittee on Reports, Accounting, and Management of the Committee on Government Operations of the United States Senate, The Accounting Establishment, Document No. 95-34 (Washington, D.C.: March 1977), 1432.

${ }^{11}$ For a more detailed description of the SEC and the development of accounting standards, see: David W. Wirick and John J. Gibbons, Generally Accepted Accounting Principles for Regulated Utilities: Evolution and Impacts (Columbus, Ohio: National Regulatory Research Institute, 1994). 
In the 19E0s, detection of large-scale fraud assumed a more important role in the audit process. This new shift in emphasis was caused by several factors: an increase in government pressure for auditors to assume more responsibility for the detection of fraud, successful lawsuits that claimed that fraud had gone undetected by independent auditors, and the belief by public accountants that audits should detect material irregularities. ${ }^{12}$

In recent years, audit procedures have been developed to detect errors and irregularities embedded in computerized financial reporting systems. In the late 1980s and early 1990s, auditors were directed to assure compliance with federal laws that had been established to prevent reoccurrence of the types of failures associated with the collapse of the savings and loan industry. ${ }^{13}$

In summary, the major shifts in auditing practice in this century have included: ${ }^{14}$

1. A shift in emphasis to the determination of fairness in financial statements.

2. Increased responsibility of the auditor to third parties.

3. A change in auditing method from detailed examination of individual transactions to the use of sampling techniques.

4. Recognition of the need to consider the effectiveness of internal controls.

5. Development of new auditing procedures applicable to electronic data processing systems and the use of the computer as an auditing tool.

6. Recognition of the need for auditors to find means of protecting themselves from the current wave of litigation.

7. Increased demand for prompt disclosure of both favorable and unfavorable information.

\footnotetext{
${ }^{12}$ Pany and Whittington, Auditing, 9-10.

${ }^{13}$ lbid., 10

${ }^{14}$ Ibid.
} 
8. Increased demand for attestation to compliance with laws and regulations by all types of organizations.

9. Demand for attestation by auditors to assertions by management about the organization's internal control structure.

As audits have evolved for other industries, the audit practices of public utility regulatory commissions have evolved as well. Until the late 1980 s, audits were often conducted in concert with rate cases and were used to identify revenue requirements. With the adoption of more flexible types of regulation in the late 1980 s and early 1990 s, the number of ratecases declined. As the focus of audits shifted away from rate As the focus of audits shifted
away from rate cases, monitoring,
reporting, compliance auditing,
and analytical reviews became
more important functions for
commission auditors. cases, monitoring, reporting, compliance auditing, and analytical reviews became more important functions for commission auditors. ${ }^{15}$

Following the discovery of huge cost overruns in nuclear power plants in the early 1980 s, public utility commissions also began to supplement their financial audits with management audits. Today, such audits may include such items as the investigation of:

...management of a public utility, including but not limited to staffing patterns, wage and salary scales and agreements, investment policies and practices, purchasing and payment arrangements with affiliated interests, for the purpose of determining inefficient or unreasonable practices that adversely affect the cost of quality of service of the public utility. ${ }^{16}$

${ }^{15}$ Tom Ferris, Wisconsin Public Service Commission, "Changes in State Regulatory Audits," a letter dated November 30, 1995.

${ }^{16}$ Alaska Public Utilities Commission Act, (Sec. 6 ch 113 SLA 1970), Section 42.05.511. 
One of the great strengths of the traditional regulatory system, and one of its greatest costs, was the recognition that data submitted to the commission by interested parties was inherently suspect.

One of the great strengths of the traditional regulatory system, and one of its greatest costs, was the recognition that data submitted to the commission by interested parties was inherently suspect.

Accordingly, administrative procedures, due process, rules of evidence, crossexamination, commission-initiated investigations, financial audits, compliance audits, management audits, and public hearings were all developed and relied upon to help verify the reliability of data, information, and testimony submitted to a commission.

\section{Types of Audits}

When the public thinks of audits, internal revenue service (IRS) audits of taxcode compliance by individuals or organizations often come to mind. When business people think of audits, they often think of the independent audits of corporations by public accounting firms. In actuality, there are three types of audits, which accomplish three distinct functions. They are:

1. Financial audits: Financial audits are employed to determine whether financial statements (the balance sheet and related statements of income, retained earnings, and cash flows) have been prepared in conformity with generally accepted accounting principles (GAAP). They are normally performed by certified public accountants who attest to the accuracy of the statements.

2. Compliance audits: Compliance audits are used to determine whether an organization meets criteria or standards such as those established by law, regulation, or even by the organization's own policies and procedures. Examples are audits of a firm by IRS auditors, examinations of banks by banking examiners, or audits of agencies receiving pubic 
funds to determine if those funds were expended in accordance with government policies.

3. Operational and management audits: Operational and management audits are used to measure the performance of a specific unit of an organization and the prudence of its decisions. Operational audits measure effectiveness and efficiency. ${ }^{17}$ According to Government Auditing Standards, performance audits are defined "as an objective and systematic examination of evidence for the purpose of providing an independent assessment of the performance of a government organization, program, activity or function in order to... facilitate decision making by parties....."18 Performance audits include economy and efficiency and program audits. ${ }^{19}$

Commission-sponsored audits of utilities can take all of these forms. A commission-sponsored audit designed to verify the accuracy of utility information submitted in conjunction with a rate case could be regarded as a financial audit, in that it may be intended to determine whether financial statements and exhibits were prepared in accordance with generally accepted and commission-ordered accounting practices. Alternatively, a state may require an independent accountant's certification that financial data are correct. In some cases, commission accountants examine the independent accountant's reports in conjunction with other financial information.

A typical commission-sponsored audit of utility fuel procurement policies and fuel costs could be regarded as a compliance audit, in that the purpose of the audit may be to determine if the utility was in compliance with commission rules and orders regarding fuel purchases, or as a performance audit to determine the effectiveness and prudence of these practices. Most commission-sponsored management audits might be regarded

${ }^{17}$ Pany and Whittington, Auditing, 10-11. The references to management audits and prudence in point 3 were added by the authors.

${ }^{18}$ U.S. General Accounting Office, Government Auditing Standards (Washington, D.C.: The Office), Section 2.6 as cited by Lisa Harvey of the Florida Public Service Commission in a letter dated February 26, 1996.

${ }^{19}$ Ibid. 
as focussed operational audits, which are conducted to determine the effectiveness and efficiency of utility operations.

Commission-sponsored audits of utilities can also be characterized as verification audits or discovery audits. ${ }^{20}$ A verification audit would verify that information submitted to the commission was accurate and prepared in compliance with commission requirements. The periodic audits by independent accountants that are required by most commissions and audits of the information submitted by a utility in a rate case are examples of verification audits. A discovery audit would attempt to identify new information of concern to regulators. For example, a management audit directed toward examination of repair and maintenance practices may identify the fact that inadequate maintenance is requiring replacement of equipment at a rate that is unacceptable to the commission because it does not conform to accepted utility practice. This distinction between verification and discovery may be useful if commissions attempt to create new models for the conduct of audits.

In addition to their ability to verify and discover information, audits are also effective tools for inducing certain behaviors. The possibility of an IRS audit is enough to cause many taxpayers to pay close In addition to their ability to verify and discover information, audits are also effective tools for inducing certain behaviors. attention to the accuracy of their returns. The understanding that the financial reports of a major corporation must be attested to as accurate by independent auditors may provide enough incentive for the corporation to keep its accounts in accordance with GAAP throughout the year. The possibility that a commission-sponsored audit might uncover utility practices that are unacceptable to the commission might help induce compliance with commission

${ }^{20}$ The term "discovery" in this context does not refer to the legal concept of discovery. Discovery, in a legal sense, is not accomplished through audits. 
rules. As a result, it can be said that, in addition to their verification and discovery functions, audits perform an implicit and explicit compliance function.

\section{The Relationship of Audits to Risk}

Audits have become so much a part of the financial and regulatory landscape that their basic purpose is often

overlooked or forgotten. Simply put, the primary purpose of an audit is to reduce information risk. ${ }^{21}$ The use of audits to coerce firms to exhibit desired behaviors Simply put, the primary purpose of an audit is to reduce information risk.

is of much less importance.

When the SEC was created, there was substantial concern that the financial statements of firms could not be relied on as accurate. Two types of risk were potentially involved--business risk and information risk. Business risk is the risk that the company will not be able to make interest payments or repay loans. ${ }^{22}$ Information risk is the risk that the financial information used to make a decision is materially misstated. ${ }^{23}$ Standard financial audits cannot directly reduce business risk; business risk is related to the business condition of the firm and its management. Audits can, however, mitigate information risk by insuring that the information presented in financial statements is accurate and comparable to information provided by other firms or by the firm itself in other financial periods. ${ }^{24}$

\footnotetext{
${ }^{21}$ Pany and Whittington, Auditing, 6.

22 Ibid., 7.

${ }^{23}$ Ibid., 6.
}

${ }^{24}$ Auditors are also concerned with audit risk, which is the risk that auditors may fail to detect errors and modify their attestations commensurately. Audit risk is divisible into inherent risk (the risk that a material misstatement occurs), control risk (the risk that the company's internal controls will not detect the misstatement), and detection risk (the risk that audit procedures will not discover the misstatement). The 
Materiality is one key to the identification of information risk. Materiality is the smallest amount of misstatement that would influence a reasonable person relying on financial statements. Auditors operate with the understandings that some information risk will always be present and that they are bound by professional standards to modify their attestations of compliance with GAAP only if material deficiencies in financial reporting are found. As a result, at the beginning of an audit, auditors attempt to quantify the level of materiality for each item to be audited. Relatively more time is then spent on material issues, and the scope of the audit is focussed on areas where material misstatement is most likely. Materiality is a function of both the amount and the nature of the item. Fraud, though the impact may be minimal financially, is by its nature serious and, therefore, material. Relatively small dollar amounts might also be regarded as material if they cause noncompliance with contracts ${ }^{25}$ Compliance audits might focus on these areas of qualitative material risk.

In the regulation of public utilities, information risk exists if commissions might make wrong decisions because of reliance on faulty information. Information risk may be related to the information provided by

In the regulation of public utilities, information risk exists if commissions might make wrong decisions because of reliance on faulty information. utilities to regulatory commissions. Confirming the accuracy of reported information (and thereby reducing information risk) is the role of the verification function of commissionsponsored audits of utilities. Information risk may also be related to information that is not automatically reported to regulatory commissions. Gaining access to that information (and further reducing information risk) is the role of the discovery function of commission-sponsored audits.

product of the three is the audit risk. Ibid., 153-154.

${ }^{25}$ Ibid., 197-199. 
Under traditional RBROR, information risk and materiality are often highest in those areas that most impact rates paid by consumers. Items that hold the highest levels of information risk and materiality are related to the cost of capital, the size of the ratebase, depreciation schedules for capital assets, initial asset valuation, and major items of annual expense, such as fuel costs or affiliate transaction costs. Although materiality is not the only factor that creates information risk, from a cost-benefit perspective, audits are generally concentrated in areas which have the greatest impact on consumers and rates. (The other factors that increase the level of information risk are described in the next chapter.)

In the future, commissions also may be concerned with information risk as it pertains to the possibility that consumers rather than commissions will make decisions based on faulty information. Limiting information risk in that circumstance may require that commissions ensure that adequate and accurate information is provided to consumers and that commissions educate consumers to make appropriate use of that information.

Designing an audit program or assessing audit needs in new regulatory environments requires an assessment of information risk. If there is no information risk in the new regulatory environment, or if commission-sponsored audits cannot reduce the risk that does exist, commission-sponsored audits will not be useful. Even the compliance function, which to some extent operates separately from the level of information risk, may be severely limited if commissions lack the authority to apply sanctions for nonperformance. In the next chapter, we will examine information risk in more detail and look at the ways some government organizations attempt to mitigate information risk. In following chapters, we will examine the information needs of regulatory commissions in traditional and nontraditional regulatory environments and attempt to assess the relative levels of information risk which attend those new environments. With that information in hand, we can then attempt to link the level of information risk with the techniques available to commissions to mitigate that risk. Those available methods include the use of commission-sponsored audits. 


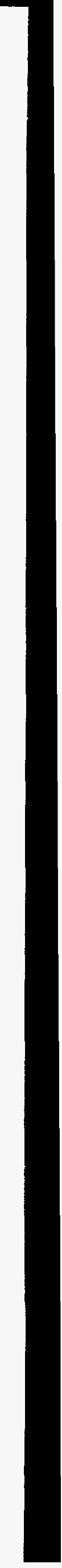




\section{CHAPTER 2}

\section{IDENTIFYING AND MITIGATING INFORMATION RISK}

Information risk in the regulatory context is the risk that commissions or consumers may make decisions based on faulty information. Audits, however, are not the only mechanism by which regulatory commissions can gather information and reduce information risk. ${ }^{1}$

In this chapter we will examine the characteristics and uses of information that cause information risk to be present. We will then identify a range of methods by which information risk can be reduced. Finally, we will examine methods for mitigating information risk applied by other regulatory agencies charged with the responsibility for protecting the public. Their experience may subsequently prove useful to state public utility commissions as they redefine their roles under alternative forms of regulation.

\section{The Characteristics of Risky Information}

Not all information carries the same level of risk. Some information is relatively free of risk. For instance, casual conversation among friends carries little or no information risk. The information is not typically relied upon for decision making, and, if it is, the decisions are not likely to be major ones. Even for regulatory commissions, some of the information received does not carry high levels of information risk. For example, the name of the utility's CEO is a piece of information contained in utility filings. That piece of information is not very risky in that substantive decisions are not

${ }^{1}$ Other common regulatory tools used to gather information include quality of service reporting, consumer complaint hot lines, public hearings, fuel adjustment clause hearings, uniform systems of accounts, depreciation analysis, financial reporting, and annual reports. In most instances commission staff analyze and verify the information submitted. 
driven by that information (except perhaps in those cases where overlapping boards of directors identify affiliates) and the information is easily verifiable.

It is in the convergence of four

Four factors that impact information risk are the magnitude of the decisions based on the information, the verifiability of the information, the materiality of the information, and the relationship between the commission and the information source. factors that information risk becomes an issue that must be dealt with by state public utility commissions. Those factors are the magnitude of the decisions based on the information, the verifiability of the information, the materiality of the information, and the relationship between the commission and the information source.

\section{The Magnitude of Decisions Based on the Information}

Under traditional cost-based regulation, information that helped determine the ratebase and the rate of return were the most significant pieces of information for state commissions. Because of their importance, they carried high information risk. In the future, other types of information may influence significant commission decisions. The greater the magnitude of the decisions based on the information, the greater the information risk. In price caps, the information identifying the size of the productivity adjustment, for example, has a high information risk because of the impact the adjustment has on prices and the evolution of competitive telecommunications markets. Similarly, where automatic pass-throughs are the method of cost recovery, as in fueladjustment charges, accuracy in submissions is very important to commissions and consumers. 


\section{The Verifiability of the Information}

Some information can be easily verified. It may be easily calculated from simple, identifiable sources or data that is reported in multiple ways. Little analysis is necessary to create this data. Some items on the utility financial statements may be described as being easy to verify. On the other hand, some pieces of information require extensive analysis and may be based upon data that is not readily accessible or often presented to the public. The cost of affiliate transactions, for example, is highly complex, based on internal utility calculations, and not reported in detail or in any standard format. Information that cannot be easily verified has higher levels of information risk attached to it than information that can be easily verified.

In price caps, information on the Gross Domestic Producer Price Index (GDPPI) is generally submitted annually by the jurisdictional utility to the commission. In this case, the magnitude of the impact is high because of the impact on prices. However, as the GDPPI is a statistic published by the U.S. Department of Commerce, verification should be relatively easy and straightforward. Verification of affiliate transaction costs, incremental cost floors, and market share information, however, would not be as easy to accomplish.

\section{The Materiality of the Information}

The magnitude of decisions based on the information is not the only factor that defines materiality. The materiality of the information is also based upon qualitative factors such as compliance with the law, contracts, or commission directives. Information is also material if a misstatement of it would change highly sensitive indicators even by a small amount. ${ }^{2}$ For example, information submitted to a state public utility commission might be regarded as material if it indicated that a

${ }^{2}$ Kurt Pany and O. Ray Whittington, Auditing (Burr Ridge, II: Richard D.Irwin, Inc., 1994), 199. 
telecommunications utility had not complied with state requirements for per line or per call blocking alternatives for Caller ID. For public utility regulators, there is also a political dimension to materiality. Though small sums may be involved in some instances, information that impacts decisions that are highly visible to consumers may be material. Service disconnection issues, for example, may impact very few ratepayers but are highly visible, and therefore, material to commissions. Material information carries higher levels of information risk than immaterial information.

\section{The Relationship Between the Commission and the Information Source}

When utilities were essentially dependent on commissions for their profitability and when commissions had strong sanctions at their disposal, utilities had a strong incentive to be cooperative with the commission and to develop a relationship based, partly, on trust. As a result, a good deal of the information provided by the utility was likely to be accurate. Now, the relationship between utilities and state regulatory commissions is in a state of flux. Utilities are not as dependent on the commission for profitability. Further, utilities are designating much information as proprietary. It appears that utilities are being very careful not to reveal information to commissions that could damage their competitive position or expose them to regulatory action. Commissions fear that utilities may attempt to unduly obstruct the necessary flow of information by identifying too much information as proprietary. As commissions manage the transition to competition, they may need more and different types of information from the utilities. In this period of uncertainty and change, information risk may increase. 
Quantification of information risk is difficult, ${ }^{3}$ but when any of the four factors just listed are present, public utility commissions need to exercise caution when they use information and may need to take vigorous steps to mitigate the level of information risk.

\section{Methods for Reducing Information Risk}

Regulation of any variety requires information. If the regulatory agency determines that information risk is present, it has many options for mitigating that risk, with the understanding that complete elimination of information risk is impossible. Six representative options, in increasing order of effort and cost, are:

- To require information to be reported by the utility, but not in any prescribed or standardized format.

- To require that the regulated company prepare its financial records in accordance with standardized procedures and record financial data in standardized accounts.

- To apply analytic procedures to check submitted company data for internal accuracy without direct, on site verification (desk audit).

- To require that the regulated company have its records audited by an independent auditing firm.

- To perform an audit using the staff of the agency or to contract with an auditing firm to perform an audit of the company at the direction of the agency.

- To independently gather necessary information without reliance on company sources of information.

${ }^{3}$ Financial auditors do attempt to quantify materiality by using guidelines or sliding scales. For example, they might use one percent of total sales for a small company as the limit for materiality. These guidelines do not take into account the qualitative aspects of materiality. (Pany and Whittington, Auditing, 199.) 
In many cases, a combination of these methods can be applied. For example, an agency could require the submission of standardized data, apply various tests to the data to identify areas of highest risk, and audit selected sources. The next four sections of this chapter detail the methods used by other regulatory bodies to mitigate information risk and to protect the public from the consequences of inaccurate or misleading information. In each case, they have applied one or more of the riskmitigating options listed above.

\section{The Securities and Exchange Commission}

The Securities and Exchange Commission (SEC) relies on a combination of standardized accounts, certification by independent auditors, and specialized audits to reduce the risk of the information reported to it and to the public. The Congress established the SEC in 1933-34 and charged it with protecting the public "...from false and misleading information by requiring publicly-owned corporations to disclose financial and other information in a manner which accurately depicts the results of corporate activities." ${ }^{4}$

In 1935, in response to abuses by utility holding companies, the SEC was also given specific authority under the Public Utilities Holding Company Act (PUHCA) to regulate the accounting, reporting, and financing of utility holding companies. ${ }^{5}$ In fulfilling these charges and achieving compliance with the accounting and financial disclosure requirements of federal securities laws, the SEC receives a large amount of financial and nonfinancial data from companies under its jurisdiction. ${ }^{6}$

${ }^{4}$ Subcommittee on Reports, Accounting, and Management of the Committee on Government Operations of the United States Senate, "The Accounting Establishment," Document No. 95.34 (Washington, D.C.: U.S. Government Office, March 1977), 173.

${ }^{5}$ Robert L. Hahne and Gregory E. Aliff, Accounting for Public Utilities (New York, NY: Matthew Bender an Company, Inc., 1993), 15.01.

${ }^{6}$ SEC jurisdiction is limited to companies having securities listed on a national exchange, issuers engaged in interstate commerce or affecting interstate commerce, or issuers whose stock is traded by 
Generally speaking, the SEC does not rely on its own audits to ensure the validity of the data received from most firms. ${ }^{7}$ The SEC, instead, requires firms subject to its jurisdiction to undergo audits by independent auditors who must then attest to the accuracy of the data to the SEC and investors. The SEC also relies on standardized accounting for reducing information risk, though it does not itself set those accounting standards.

Early in its history, the SEC delegated the establishment of accounting standards to the accounting profession. In 1938 , the SEC stated that:

In cases where financial statements filed with this Commission...are prepared in accordance with accounting standards for which there is no substantial authoritative support, such financial statements will be presumed to be misleading or inaccurate..... ${ }^{8}$

With that statement, the SEC gave the accounting community the authority and incentive to establish standards that might be regarded as having that "substantial authoritative support." Through a succession of organizations, most recently the Financial Accounting Standards Board (FASB), the accounting profession has established accounting standards that are applicable to all firms audited by professional accountants. Though the SEC has overruled the FASB in rare instances, in general it has affirmed the accounting standards established by the FASB. The SEC also puts the teeth in FASB pronouncements through its broad enforcement and disciplinary powers.

With regard to utility holding companies regulated by the SEC under PUHCA, the SEC has set the goal of conducting a desk or field audit of each service company every

mail if certain other criteria are met.

${ }^{7}$ The SEC performs more detailed examinations of securities brokers and dealers.

${ }^{8}$ Securities and Exchange Commission, "Release No. 4, April 25, 1938, Administrative Policy on Financial Statements," as cited in Subcommittee on Reports, Accounting, and Management of the Committee on Government Operations of the United States Senate, The Accounting Establishment, 1432. 
three years. The SEC also attempts to do a desk or field audit every three years of the twenty-six special purpose corporations with substantial investments in energy-related businesses. SEC audits focus primarily on affiliate transactions. The SEC coordinates its audits of the service companies with the Federal Energy Regulatory Commission (FERC) and invites participation in its audits by state commissions with jurisdiction over the utility subsidiary of the registered holding company.

As the companies under the jurisdiction of the SEC operate in workably competitive markets, the SEC feels comfortable in generally relying on independent audit firms, with selected field and desk

As Congress considers repeal or revision of PUHCA, public utility regulators will need to be concerned with the treatment of Section 15 of the Act as it addresses the authority to conduct audits of holding companies, the requirements for utility record-keeping, and access to company records. audits by SEC staff. As Congress considers repeal or revision of PUHCA, public utility regulators will need to be concerned with the treatment of Section 15 of the Act as it addresses the authority to conduct audits of holding companies, the requirements for utility record-keeping, and access to company records. This is an important feature not

to be lightly lost in "regulatory reform" activity.

\section{The U.S. Department of Transportation}

The United States Department of Transportation (DOT) is the focal point for federal transportation policy. It is responsible for transportation safety, enforcement of safety standards, international transportation agreements, and the continuity of transportation services in the public interest.

Though the Federal Aviation Administration (FAA) has authority over airline companies, substantial information verification and auditing are left to the DOT. The 
information provided by the airlines to the DOT includes market data for foreign and U.S. carriers, on time performance data, financial data, passenger origin-destination surveys, and commuter carriers' traffic and financial data.

The DOT employs several methods to confirm the accuracy of the data provided. It requires that the financial data provided by major carriers be certified by independent auditors. It also employs six automated data bases and four nonautomated data bases containing carrier information to review the data to identify potential problem areas. If the DOT determines that on site evaluation is necessary, it notifies the Office of the Inspector General to conduct an on site audit. These on-site audits are fairly rare; only two have been performed in the past several years.

The DOT situation is interesting because the regulatory agency, the FAA, outsources its information verification function to a parent line agency. Like the SEC, the DOT relies on independent auditors and desk audits to minimize information risk.

\section{The Federal Deposit Insurance Corporation}

The Federal Deposit Insurance Corporation (FDIC) ensures the safety and soundness of insured depository institutions and, by doing so, maintains public confidence in the nation's banking system. The FDIC identifies, monitors, and addresses risks to the safety of deposited funds and assures fairness in the sale of financial products and the provision of financial services.

The FDIC operates an aggressive system of audits and checks on submitted data. Publicly traded banks are audited by FDIC auditors annually. Other banks are audited less often than the publicly traded banks but are audited at least every three years.

Every six months, banks submit a report to the FDIC that identifies such information as the capital structure, assets, the portfolio balance, loan data, the equity ratio, and management information. In its Off Site Monitoring System, FDIC examiners 
check the data, using indicators to identify possible fraud. For example, they closely examine capital ratios to identify dramatic changes during the period.

While the FDIC applies a range of information verification tools, its main tool is the use of on site audits by FDIC staff or its contractors. The SEC uses a lower level of oversight because it is somewhat easier for financial markets to verify the information of publicly traded corporations than it is for the average bank depositor to determine the financial integrity of his or her bank.

\section{The Environmental Protection Agency}

The Environmental Protection Agency (EPA) protects and improves the physical environment of the nation. In cooperation with state and local governments, the EPA controls pollution through standard setting, enforcement, and research in six pollution areas: air, water, solid waste, toxic substances, radiation, and noise.

The Office of the Inspector General (OIG) of the EPA conducts various types of audits, which include performance audits, financial audits, and investigation of allegations of violation of Federal law and regulations. OIG performance audits determine whether the agency is acquiring, protecting, and using its resources economically and efficiently, and whether programs and activities have achieved the desired results or benefits established by the Congress. Financial audits review the records of organizations or entities receiving financial assistance or benefits from the EPA, such as grant recipients, contractors, and subcontractors.

The EPA attempts to mitigate information risk through field and desk audits. It does not depend on financial information to the same extent as the SEC and the FDIC and, accordingly, relies less on independent auditors. Oversight is especially important for the EPA because of the limited verification opportunities it has. Much controversy, of course, centers on information gathered by the EPA because of the magnitude and materiality of its impact on EPA decisions and, in turn, their impact on the environment. 


\section{Conclusion}

There are many ways to reduce information risk. The choice of method depends upon the information requirements of the regulatory regime and the level of information risk inherent in the data. The absence of standardized financial reporting, for example, does not necessarily mean that less regulation is occurring. Ideally, it should mean that the regulatory organization has decided that the information risk associated with a particular piece or class of information is too low to require standardized reporting. It may be that multiple and correlated sources of information exist, or that the standardized reports already produced by the utility for its other purposes are sufficient. It could also be that the information required is needed but of marginal value, such that a cost-benefit appraisal does not support enforcement of a standardized reporting requirement.

Each of the four regulatory agencies briefly examined above made clear and conscious decisions about the level of risk inherent in the information necessary to accomplish their missions. From a public policy perspective, a problem occurs when there is no congruence between the tool employed to reduce risk and the level of information risk. Overregulation occurs when the verification

From a public policy perspective, a problem occurs when there is no congruence between the tool employed to reduce risk and the level of information risk.

tool is more powerful and hence more costly than can be justified by the information risk. Under-regulation results when high risk information is subject to inadequate verification. Over- and under-regulation result in inefficient allocation and suboptimal regulatory outcomes. As we will show in Chapter Four, the optimal level of verification occurs when there is a reasonable congruence between the risk and the level of verification and when the cost of information risk-mitigation options approximately equals the benefit gained. 


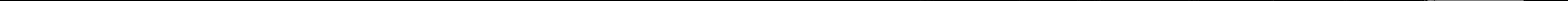




\section{CHAPTER 3}

\section{FUTURE COMMISSION DECISIONS AND INFORMATION NEEDS}

It is axiomatic that the provision of utility services is undergoing dramatic change, and, as a result, the role of state public utility commissions is also likely to substantially change. Indeed, the purpose of this report is to examine the role of commissionsponsored audits, not in the traditional regulatory environment, but in the regulatory environment that is now emerging.

But what specific changes are occurring in utility markets and in state regulation of the utilities? For the Commissioners Summit held in April of 1995 by the National Association of Regulatory Utility Commissioners (NARUC) and the National Regulatory Research Institute (NRRI), the staff of the NRRI identified the following ten major trends in utility service delivery:

- Dichotomy of customers into core and noncore groupings.

- Unbundling and new service offerings.

- Deregulation of certain services and markets.

- Increased use of market-based pricing and incentive rate making.

- $\quad$ Large users seeking lowest-cost service providers.

- Shift from the old regulatory compact in regards to territorial exclusivity and assured recovery.

- Changing obligation to serve.

- Utility diversification into other businesses and use of holding company structures.

- Increasing business risk for utilities. 
- Uncertainty as to continued attention to social goals. ${ }^{1}$

Any prognostication of future conditions or the regulatory reaction to those conditions is certainly subject to error. Indeed, legislative changes at the state and federal level may considerably shape the future environment and may preempt the best laid commission, utility, or consumer plans. However, merely reacting to changes as they overtake commissions would not serve the public interest well. Active regulation and simple prudence demand some attempt to discern the future and to prepare for it.

In the next two sections of this chapter, we attempt to identify the decisions that commissions likely will make in the future and the information necessary to support those decisions. We employ two

We suggest a five-step process for managing information risk:

(1) identification of decisionmaking requirements,

(2) identification of information necessary to support decisions,

(3) evaluation of information risk,

(4) identification of options to mitigate that risk, and, ultimately,

(5) cost-benefit analysis of the applicable methods for mitigating information risk. methods: (1) extrapolation from the results of the NARUC/NRRI Commissioners Summit that was mentioned earlier in this chapter, and (2) a facilitated discussion with a dozen senior members of the staff of the Ohio Public Utilities Commission (PUCO). The first provides a macro view of decision and information needs; the second provides a micro view of the hands-on needs of a state commission. For the PUCO exercise, we also asked participants to identify information risk inherent in the information needed for future decision making. From the results of both

${ }^{1}$ The Staff of the National Regulatory Research Institute, Missions, Strategies, and Implementation Steps for State Public Utility Commissions in the Year 2000: The Proceedings of the NARUC/NRRI Commissioners Summit (Columbus, Ohio: NRRI, 1995), 1-2. 
exercises, we are able to better understand and illustrate the types of information that are likely to be necessary for effective regulation in the future.

Because of the inherent levels of uncertainty involved in these future-oriented exercises, the step-wise method of analysis we suggest (i.e., (1) identification of decision-making requirements, (2) identification of information necessary to support decisions, (3) evaluation of information risk, (4) identification of options to mitigate that risk, and, ultimately, (5) cost-benefit analysis of the applicable methods for mitigating information risk) is more important and useful than the specific results we obtained. And though neither of the two exercises will be the last word on decisions, information needs, or information risk, the similarities between the results do provide some measure of confidence of their validity.

Why did we choose this step-wise method, focusing first on decisions and only later on information needs? Simply put, if the decision-making role of state commissions is minimized, their need for information and concern with information risk will also be minimized. The types of information collected impact the level of risk, and the level of risk determines the need for audits or other methods for mitigating information risk.

\section{The NARUC/NRRI Commissioners Summit}

In April of 1995, the NRRI and the NARUC convened a two-day summit meeting of public utility commissioners to discuss the future of regulation. Commissioners participated in facilitated exercises designed to identify the missions, strategies, and implementation steps for state public utility commissions in the year $2000 .^{2}$

Though no attempt was made at that summit to explicitly identify the types of decisions commissions will make in the new regulatory environments or the types of

\footnotetext{
${ }^{2}$ For more information, see Staff of the NRRI, Missions, Strategies, and Implementation Steps for State Public Utility Commissions in the Year 2000: Proceedings of the NARUC/NRRI Commissioners Summit (Columbus, Ohio: NRRI, 1995).
} 
information necessary to support those decisions, clear inferences can be drawn from the output of the summit. Often, when commissioners identified a mission or strategy, they established a clear need for information. The five overall missions identified at the summit are listed below along with information needs relative to each as cited by participating commissioners. The missions were: (1) services to core customers, (2) competitive services, (3) utility managers and shareholders, and (4) social goals, and (5) new requirements. ${ }^{3}$

\section{Services to Core Customers}

Commissioners at the summit expressed wide agreement that state public utility commissions would need to protect certain utility customers in those segments of utility markets where all customers did not uniformly benefit from competition. In order to carry out regulatory decision-making responsibilities, participants at the summit identified the following information as relevant to protecting core customers.

- $\quad$ Service quality--To support the commission missions of (1) ensuring adequate, safe, reliable, and affordable services for core customers... and (2) ensuring the appropriate level of oversight for service provided to those who will not reap the full benefits of competition.

- Utility financial information--To support the commission mission of ensuring investments in services for core customers. To support the commission strategies of (1) rebalancing rates and removing crosssubsidies, and (2) compensating adequately the carrier of last resort.

- Market information including market share--To support the commission mission of bringing down barriers that keep core customers from access to competitive services.

- Affiliate transaction information--To support the strategies of (1) of ensuring that noncompetitive services do not subsidize competitive

\footnotetext{
${ }^{3}$ For the sake of brevity, the references to the Proceedings of the summit are not separately footnoted throughout the remainder of this chapter.
} 
services and (2) developing new criteria for analysis of competitive and affiliated interests.

\section{Competitive Services}

Commissioners strongly supported competition but tempered their support with an interest in ensuring that competition is fair and effective. Information needs drawn from their missions and strategies supporting competitive services are:

- $\quad$ Market and pricing information--To support the commission missions of (1) supporting competition where it improves efficiency and innovation; (2) defining, monitoring, and measuring competition and defining when effective competition exists; (3) securing necessary information for handling a transition period--preventing abuse of economic power. To support the strategy of providing the utility flexibility in pricing necessary to promote competition by non-competitive companies subject to regulatory review.

- Utility financial information--To support the commission mission of providing oversight of infrastructure to maintain quality and performance.

- Market share information--To support the strategy of vigorously applying antitrust principles.

- Service quality information--To support the strategy of focusing on service reliability and consumer protection.

\section{Utility Managers and Shareholders}

Commissioners at the summit asserted that utility managers would need to be given the tools to compete in the new marketplace. They also recognized that utilities would face additional financial risk. The following information was identified as necessary to support commissions in their pursuit of their general objectives of 
providing utility managers with adequate competitive tools and compensating the utility for increased risk:

- Utility financial information and market information--To support the commission mission of identifying instances where adoption of risk-reward mechanisms commensurate with shareholder risk are appropriate.

- $\quad$ Customer information--Participants suggested that utilities should be more responsive and accountable to customers.

- Utility financial information--To support the strategy of valuing stranded investments and moving toward competition.

\section{Social Goals}

Participants at the summit recognized that methods for the achievement of social goals would need to be revised given the transition to competitive markets. Information necessary for the redefinition of social goals and the methods by which they are achieved included:

- The cost of social goals--To support the commission mission of encouraging a shift to general revenue funds for the achievement of social goals. To support the strategies of (1) identifying social goals, to determine which can be reached through regulation, and to determine which are the responsibility of taxpayers/ratepayers/stockholders, and (2) looking at ways to subsidize high cost and under-served (low income) customers.

\section{New Requirements}

Participants at the summit identified several new commission requirements for the new utility environment. Those new requirements fell into four general groups--the impact of new corporate structures, jurisdictional changes, necessary changes in 
regulatory methods, and customer protection in the new environment. Information requirements that can be linked to those new requirements were:

- Utility financial information--To support the commission mission of evaluating mergers and acquisitions (including international).

- Affiliate transaction information-To support the commission mission of assuming greater responsibility for monitoring affiliate transactions. To support the strategy of employing structural separation of affiliates and holding companies and monitoring and responding to diversification actions of utilities.

- Market information--To support the commission mission of advocating an appropriate level of local jurisdiction over the way in which markets develop.

- $\quad$ Service quality information--To support the commission missions of (1) identifying quality of service and system reliability standards in changing markets; and (2) preventing antitrust, collusive, and anti-consumer behavior during the transitional period. To support the strategies of (1) periodically surveying the market to confirm customer and service definitions and (2) adapting or revising quality-of-service standards and evaluating rules for enforcement.

\section{Assessment by Staff of the Public Utilities Commission of Ohio}

Twelve senior staff members ${ }^{4}$ representing various offices within the Public Utilities Commission of Ohio (PUCO) were asked to identify in an NRRI structured and facilitated process the types of decisions that they felt the commission was likely to be faced within the new utility operating environment. They were then asked to identify the

${ }^{4}$ Frank Rack, Mary Kay Fenlon, John Tucker, David Hodgden, Carl Evans, Tom McNamee, Michael Weiss, Jeff Devore, Jerry Wissman, Debbie Hensel, Kerry Stroup, and Gretchen Hummel. 
information necessary to support those decisions and to rank the information by its importance and how difficult it is to collect. ${ }^{5}$

After the likely decisions were articulated, they were grouped by the participants into four broad categories: competition, rate setting, quality of service, and management performance and regulatory oversight. ${ }^{6}$

\section{Competition}

The "competition" category of likely commission decisions included: ${ }^{7}$

- Identifying methods to promote competition.

- Determining to what extent the PUCO should promote competition.

- Determining whether end-use competition exists.

- Determining the difference between competitive and anti-competitive actions.

- $\quad$ Determining whether a duopoly market is adequately competitive.

- Identifying the appropriate level of concern about equity shortfalls associated with competition.

- Identifying anti-competitive pricing practices.

- Identifying punitive actions to be taken for anti-competitive practices.

- Assessing the viability of the core/noncore distinction.

- Guaranteeing that the benefits of competition endure.

- Identifying commission responsibility for ensuring a level playing field for new entrants.

- Measuring market share.

${ }^{5}$ The results of this exercise do not necessarily represent the opinions of the PUCO Commissioners or of the PUCO itself. They are merely ideas expressed by knowledgeable staff members.

${ }^{6}$ Three decisions could not be placed into any one of these categories. They were: Is a new definition of a public utility needed? Is the regulated/unregulated distinction necessary? Can the PUCO change from a numbers-driven process to a management- and operations-driven process? They were not given further consideration in our analysis.

${ }^{7}$ In this and the other categories, the decisions identified were sometimes reformatted for consistency and clarity. In a few instances, participants felt that decisions should be listed in more than one category. 
The information identified as necessary to support those competitive decisions included:

- Financial information.

- Information on the underlying technology.

- Market share and market share definitions.

- Federal requirements.

- The magnitude and importance of service to social goals.

- Risk analysis of choosing competitive options.

- Information on whether alternative providers can do the job for a lower total cost.

\section{Rates}

The "rates" category of likely commission decisions included:

- Identifying cross-subsidization.

- Identifying reasonable prices and quality of service for captive customers.

- Identifying the impact of tax changes.

- $\quad$ Pricing captive services to recover costs.

- Responding to excess profits.

- $\quad$ Allocating costs between generation, distribution, and transmission.

- Verifying asset information.

- Determining performance standards.

The types of information necessary to support this category included:

- Tariff and cost-of-service information.

- Performance standards and performance measurement.

- Financial information.

\section{Quality of Service}

In the "quality of service" category, participants identified the following: 
- Identifying the necessary level of end-user quality-of-service protection.

- Determining performance standards.

- Determining whether alternative providers and utilities will be required to meet minimum telephone service standards in a fully competitive market.

- Identifying reasonable prices and quality of service for captive customers.

- Determining remaining product safety concerns.

- Identifying criteria for abandonment-of-service requests.

- Preventing the duplication of facilities.

The types of information identified as necessary to support these decisions were:

- Safety information.

- Minimum service levels.

- Consequences of not meeting customer standards.

- $\quad$ Product dangers.

\section{Management Performance and Regulatory Oversight}

The "management performance and regulatory oversight" category contained a number of decisions carried over from more traditional regulatory environments. They were felt to be necessary because of the likely continuation of RBROR regulation in some form for some providers. Decisions included in this category were:

- Identifying the efficiency of company cost control.

- Identifying and protecting proprietary data.

- Determining whether or not the commission should be concerned with a utility's strategic plan.

- Identifying required versus allowed services.

- Maintaining existing accountability for the utility component of the social infrastructure.

- Determining the need for a financial approval process.

- Identifying the appropriate accounting system for utilities.

- Dealing with stranded investments.

- Making siting decisions.

Information deemed necessary to support these types of decisions included: 
- Uniform accounting and financial information.

- Strategic planning documents.

- Computation of financial and performance ratios.

- Affiliate transaction information.

- Company organization, reporting, and management information.

- Tracking mechanisms.

- Impact of utility financial goals on quality-of-service goals.

- Basic company data (regulated and unregulated) for comparison.

- Information on management intentions.

- Access to traditional utility information.

- Environmental power-siting information.

\section{PUCO Staff Assessment of Information Risk}

Two of the four factors that indicate the presence of information risk are the importance of the information and the lack of verifiability of the information. (The other two are the materiality of the information and the relationship between the source of the information and its user.) We asked PUCO staff participants to identify through a simple voting technique the "importance of the information" and which information elements of those listed were "hardest to get." It is recognized that while many commissions may agree with the PUCO staff identification of necessary information, others may assign different relative weights.

The information the PUCO staff regarded as most important was: (The number of votes each information element received is listed in parentheses in order to illustrate the relative level of importance of each information element.)

- Information on performance standards and service levels (11). ${ }^{8}$

- $\quad$ Risk analysis of choosing competitive options (7).

- Magnitude and importance of service to social goals (5).

- Uniform accounting and financial information (4).

${ }^{8}$ This element of information combines three similar elements: Performance standard information (Rates), Minimum service levels (Quality of Service), and Information on the consequences of not meeting standards to the customer (Quality of Service). 
- Environmental information for power siting (3).

- Is proprietary information considered competitive (3).

The information they regarded as the hardest to get was: (The number of votes is shown as a means of illustrating the relative difficulty of getting each piece of information.)

- $\quad$ Can alternate providers do the job for a lower cost (11).

- Magnitude and importance of service to social goals (8).

- Information on management intentions and the impact of utility financial goals on quality-of-service goals (8). ${ }^{9}$

- Risk analysis of choosing competitive options(6).

- Affiliate transaction information (6).

- Market share information and market share definition (4).

- Information on underlying technologies (3).

- Product dangers (3).

These items (and particularly those with the highest scores) are the information elements that, according to our exercise with the PUCO staff, have the highest levels of information risk. Of particular note, are those elements that appear on both lists (i.e., that have high levels of importance and are difficult to verify).

This exercise was not intended to produce a definitive forecast of forthcoming regulatory issues or information requirements. Instead the objective was to get some concrete, linked examples of forthcoming issues, and some of the information needed to support decision making about the identified issues. Having commission staff assess the need for and difficulty in obtaining specific types of information gives some tangible indication of the scope of the problem. It is important to note that the commission staff had no difficulty in identifying those pieces of information that would be important to have and difficult to obtain.

\footnotetext{
${ }^{9}$ This element combines two similar elements both from the Management category.
} 


\section{Conclusions}

Though every commission will differ to some extent and may assign different priorities to information needs, some generalizations can be made. Indeed, the results of the PUCO exercise and the commissioners summit reveal a high degree of correlation between their assessments of information needs. Both agree that decision making will continue to be a function of regulatory commissions and that information will be necessary to support that decision making. Both identify information needs for existing types of regulation, which will continue for certain segments of the utility industries. In the PUCO exercise, the "rates"

Both exercises identified information needs for existing types of regulation, both identified information needs for the transition from traditional regulation to more competitive utility markets, and both identified the need to generate information to support commissions as they operate in competitive markets.

category and the "management

performance and regulatory oversight" sections addressed the need for some traditional information. In the summit, the "services to core customers" mission addressed the need to perform traditional analysis and regulation for those customers who might never reap the full benefits of competition.

Both identified information needs for the transition from traditional regulation to more competitive utility markets. In the PUCO exercise, these transformative issues were sometimes expressed as the need for the commission itself to identify appropriate roles and regulatory strategies. At the summit, commissioners indicated their intention to support competition but tempered that support with their interest in ensuring that the competition is fair and effective.

Both exercises also identified the need to generate information to support commissions as they operate in competitive markets. The information needs identified as necessary for competitive markets indicate a change from the traditional information 
needs and sources, such as the reliance on utility financial and cost data. The new needs include an increased emphasis on measures of consumer satisfaction, quality of service, the market impact of utilities in competitive or partly competitive markets, and measures designed to support the monitoring of affiliate transactions.

Possibly, the most important result of these two exercises was the identification of the types of information needed by commissions. Overall, the information necessary for commission oversight as defined by the two analyses can be summarized, however imperfectly, into five major categories. They were:

- Market information.

- Quality-of-service and customer-satisfaction information (including the development of utility performance standards).

- Utility financial information.

- Social cost information

- Information on affiliate transactions.

With regard to the level of risk inherent in these categories of information, though the PUCO staff assessment of information risk did not specifically address these five categories of information, their assessments of more specific information elements indicated that each of these five general categories might contain relatively high levels of information risk. All five were contained within more explicit items on the PUCO staff list of "hardest to get" information. In addition, three (or four depending on interpretation) of these categories were identified among the four most important commission needs.

Only two of these five categories (utility financial information and affiliate transaction information) rely on traditional information gathering techniques employed by public utility commissions. Utility financial information can be gathered through the provision of information by the utility or examination of utility financial and cost 
information and verified using traditional verification tools, including audits. Market information, social cost information, and quality-of-service and customer satisfaction information cannot satisfactorily be provided to commissions by utilities and may require commissions to shift the emphasis of their staff from traditional audits to other techniques of information gathering and verification.

In some cases, that shift has begun. The staff of the Florida Public Service Commission has been involved in such issues as a survey of customer Collecting market information, social cost information, and quality-of-service and customer satisfaction information may require commissions to shift the emphasis of their staff from traditional audits to other techniques of information gathering and verification. In some cases, that shift has begun.

satisfaction and the development of a market survey on inside wire competitors. The staff of the Colorado Public Utilities Commission participated in public forums to develop a consumers' Bill of Rights. The Ohio Public Utilities Commission is developing a survey of consumers that will be used to update the state minimum standards for telecommunications services. 


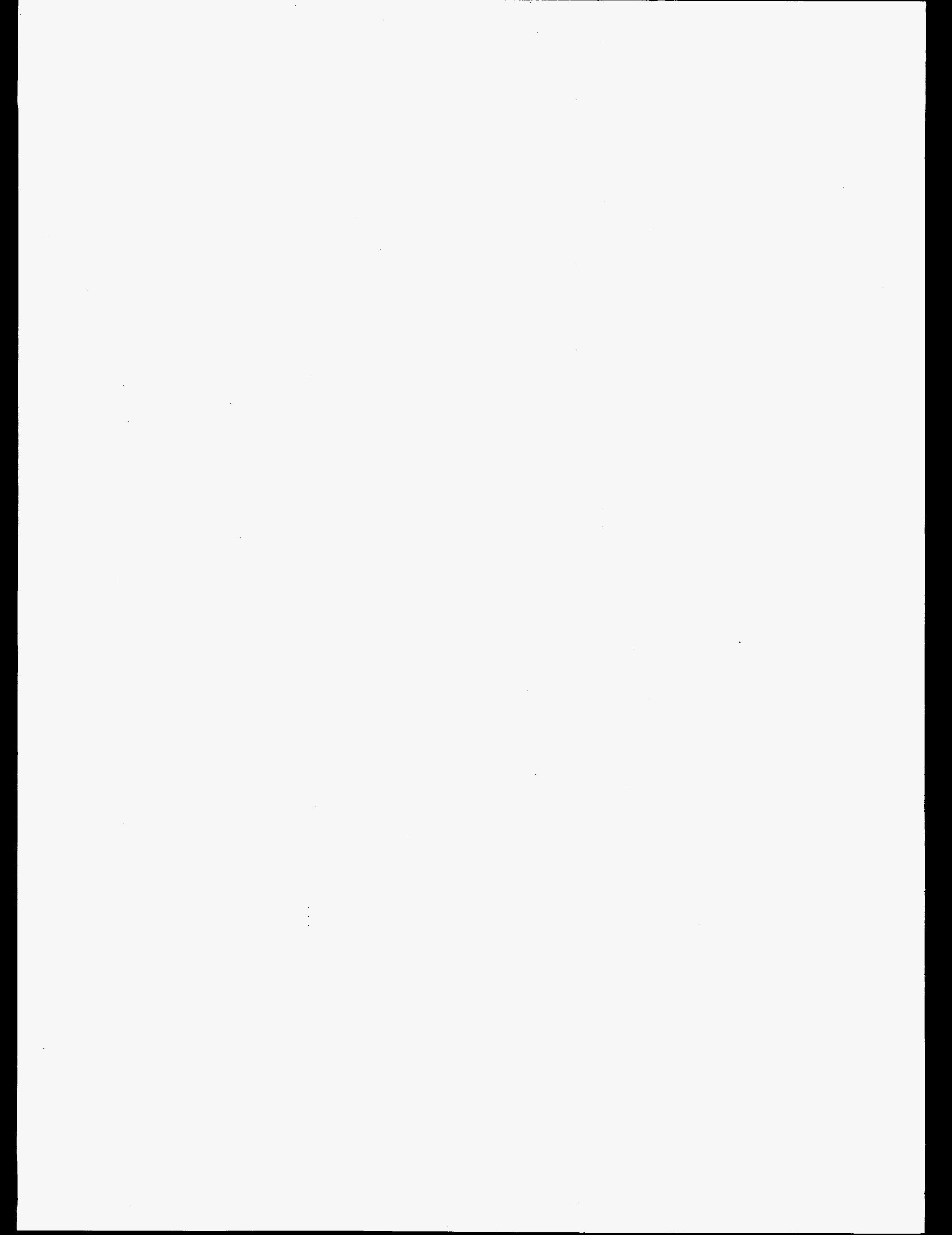




\section{CHAPTER 4}

\section{COST-BENEFIT EVALUATION OF METHODS TO MITIGATE INFORMATION RISK}

The decision to perform an audit should be based on the need to make a decision, the need for information, the information risk inherent in the required information, and the consideration of the range of methods by which the risk can be mitigated. This chapter lays out a more specific cost-benefit analysis that can be employed to evaluate the need for commission-sponsored audits though it may be more useful as a mental paradigm than a quantitative exercise. It also discusses the process for selecting the most effective method of mitigating information risk in the context of public utility regulation.

\section{The Evaluation Model}

A goal of public utility commissions should be to reasonably mitigate information risk using the lowest-cost alternative. Put another way, commissions should invest in risk-mitigating techniques until the marginal cost of the effort to mitigate risk exceeds the benefit. In selecting methods to mitigate information risk, commissions should also consider the

Commissions should invest in risk-mitigating techniques until the marginal cost of the effort to mitigate risk exceeds the benefit. fact that some information risk will always be present. Risk can be reduced to the extent that it is not very likely that wrong decisions will be made because of inaccuracies in the information, but information risk can never be completely eliminated. Even complete self-collection of information still contains some information risk due to the possibility of collection errors. Nor is the complete elimination of information risk a worthy public policy goal. 
Cost-benefit analysis is one technique that allows a comparison of alternatives. As cost-benefit analysis is applied to the choice of options to mitigate information risk, the identification of costs is fairly straightforward. Costs of a commission-sponsored audit include salaries, benefits, training costs, travel, office space, and materials as well as the costs to the utility to host the auditors and provide data and space. Sunk costs, costs that were incurred in the past that will not be effected by current or future decisions, ${ }^{1}$ need not be considered. For example, the identified costs of an audit would not include the costs incurred by the utility to conform to generally accepted accounting principles since that decision was made in the past and the practice will be continued into the future regardless of the audit decision.

It is as easy to over-estimate the cost of regulation as it is to under-estimate these costs. For example, while it may seem at first glance that the full cost of a standardized financial reporting system

Many regulatory costs have the effect of minimizing the information risk for financial and other markets. mandated by the commission should be included in the cost-benefit analysis, in actuality, some of these costs may have had to be incurred by the utility in order to satisfy other requirements. Many

regulatory costs have the effect of minimizing the information risk for financial and other markets. It may also be the case that some of the costs of pollution control should be assigned to environmental protection regulation and not be included in the economic regulator's cost responsibility in a cost/benefit analysis.

Except for small utilities, the costs of producing information is almost always very low relative to total utility operating costs, though utilities have traditionally argued that the cost of audits and of providing regulatory compliance information is too high. As the total direct cost of state regulation is around one tenth of one percent of a jurisdictional

${ }^{1}$ Joel C. Siegel and Jae K. Shim, Dictionary of Accounting Terms (Hauppauge, NY: Barron's Educational Series, Inc., 1987), 416. 
utility's intrastate revenues, it would be inaccurate to assign high costs to an audit. ${ }^{2}$ The test here, of course, is the need for the information.

As usual, benefits are more difficult to quantify. Some of this difficulty occurs because of the qualitative nature of some benefits, such as clean air or better planning by the utility. Another source of measurement difficulty arises when the analyst "over claims" the benefits to be realized. Over claiming is somewhat common because the enthusiasm of proponents often clouds their judgement. A common example of this is when positive changes in the state's general economy are attributed to relatively minor regulatory changes.

In order for a benefit to be properly claimed by an analyst, the analyst has a burden of proof to show the linkage of the regulatory or utility action to the posited benefit. This is not always a problem as many benefits can be specified with reasonable accuracy. When identifying the benefits associated with reducing information risk, financial and management audits invariably identify benefits that far exceed the direct cost of the audit by several magnitudes. Some of this may be due to over claiming, but even

It is still fair to say that the benefits obtained by the vast majority of regulatory audits more than cover their direct costs. As long as benefits of audits continue to significantly outweigh their costs, audits should be expected to continue as a reliable regulatory tool. after applying a large discount factor, it is still fair to say that the benefits obtained by the vast majority of regulatory audits more than cover their direct costs. As long as benefits of audits continue to significantly outweigh their costs, audits should be expected to continue as a reliable regulatory tool.

\footnotetext{
${ }^{2}$ Vivian Witkind Davis, Raymond Lawton, Edwin Rosenberg, An Analysis of Selected Aspects of Ohio Bell Telephone's Application for Price Caps, Service Classifications, and Infrastructure Commitments (Columbus, Ohio: NRRI, 1994), 145.
} 
In general, the benefits attributable to risk-mitigation efforts are better commission decisions and less chance that faulty information would cause the wrong decisions to be made. Ultimately, the benefits of improved commission decision making are improved social welfare and more efficient pricing and use of utility services. These are valuable outcomes indeed.

A cost-benefit evaluation of options for mitigating information risk is graphically illustrated in Figures 4.1 through $4.4 .^{3}$ In Figure 4.1, the vertical axis identifies mitigation methods. The horizontal axis measures the information risk. As you move out along the horizontal axis, the probability that the commission will make "the wrong decision" based on faulty information increases. ${ }^{4}$ Figure 4.1 indicates the simple fact that, for any specific piece of information, the level of information risk goes down as more vigorous mitigation methods are applied. For example, for a particular type of information (e.g., affiliate transaction information) the application of mitigation method $\mathrm{MM}_{2}$ would generate risk level RL2. If $\mathrm{MM}_{4}$ were applied, the risk would drop to RL1.

The slope of the curve for each piece of information is very important. Figure 4.2 identifies a different relationship between mitigation methods and risk. In Figure 4.2, the application of $M M_{1}$ produces risk level $R L_{2}$. The application of $M M_{2}$ reduces the risk to RL1. Note, however, that little or no additional benefit is achieved by the application of $\mathrm{MM}_{3}$ or $\mathrm{MM}_{4}$. It is also conceivable that, under certain conditions, no available mitigation method would reduce risk.

Figure 4.3 displays the simple, presumed relationship between mitigation methods and costs. It suggests that costs increase as mitigation methods become more vigorous (and more effective).

${ }^{3}$ In these figures, it is assumed that risk-mitigation methods can be combined to create a wide array of options. This wide array allows for the creation of continuous curves. If mitigation methods could not be combined, the curves would be replaced by stepwise functions though the conclusions and the analytic methods would not change.

${ }^{4}$ There are many factors, many of them subjective, that influence the "correctness" of commission decisions. We are only concerned in this report with the impact of accurate information. 
From these two simple relationships, Figure 4.4 can be created and the method for choosing the appropriate mitigation method can be illustrated. In Figure 4.4, the down sloping line (MB) represents the marginal benefits realized from the application increasingly vigorous mitigation methods. It slopes downward due to the presumption of diminishing marginal returns from the application of successive mitigation methods. That diminishing marginal returns exist is unquestionable; the exact slope of the curve is subject to debate.

The up sloping line $(\mathrm{MC})$ represents the marginal costs of the application of successive levels of mitigation methods. The marginal cost curve is presumed to be $U$ shaped because marginal costs typically decline over an efficient range where fixed costs are averaged across more units of production but then increase beyond the efficient range. For each type of information the commission needs to gather, the shape of the curve will be different.

From Figure 4.4, the optimal risk mitigation strategy can be identified. On Figure 4.4, the marginal cost of $M M_{1}$ is the distance $O C$ (which is derived from

The simple lesson from costbenefit analysis is that the commission should apply additional risk-mitigation strategies until the costs of the effort exceed the benefits of the effort. Though "hard data" may not always be available, commissions are skilled at making judgements under conditions of uncertainty and at balancing intangible costs and benefits. the point at which $M_{1} M_{1}$ intersects the marginal cost curve $M C$ ). The marginal benefit of $M M_{1}$ is $O D$, derived from the point at which it intersects the marginal benefits curve MB. Since marginal benefits significantly exceed marginal costs, the commission should move to a higher-cost option.

The marginal cost of $\mathrm{MM}_{3}$ is $\mathrm{OB}$. Its benefit is only $\mathrm{OA}$. Marginal costs substantially exceed marginal benefits at $\mathrm{MM}_{3}$, and as a result, the commission should adopt a mitigation option that costs less. 
The optimal choice for the commission is to adopt a risk mitigation option or combination of options that corresponds to the intersection of MC and MB. In this case $M_{2}$ comes very close to meeting that criterion. If the commission were unable to find a set of options that perfectly corresponds to that point, the commission should choose the set of options closest to it as long as marginal benefits still exceed the marginal costs.

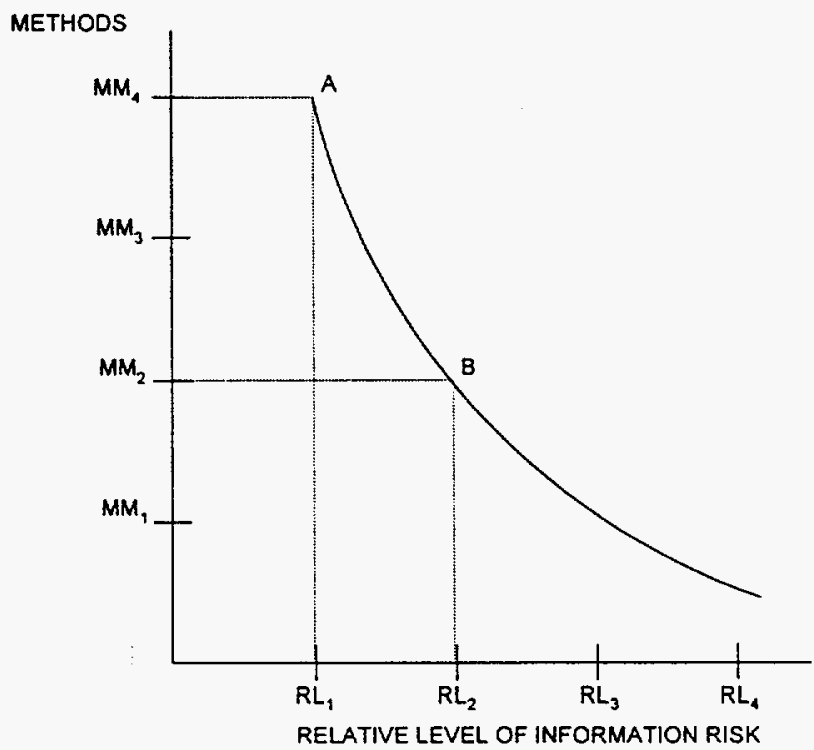

Figure 4.1. The relationship between mitigation methods and information risk. 


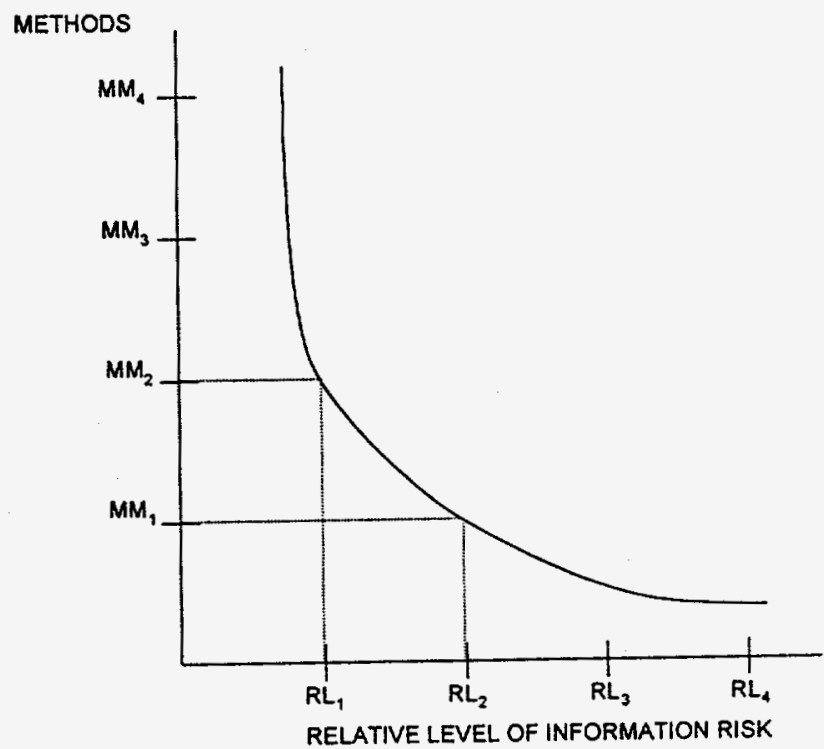

Figure 4.2. Demonstration of the importance of the shape of the curve.

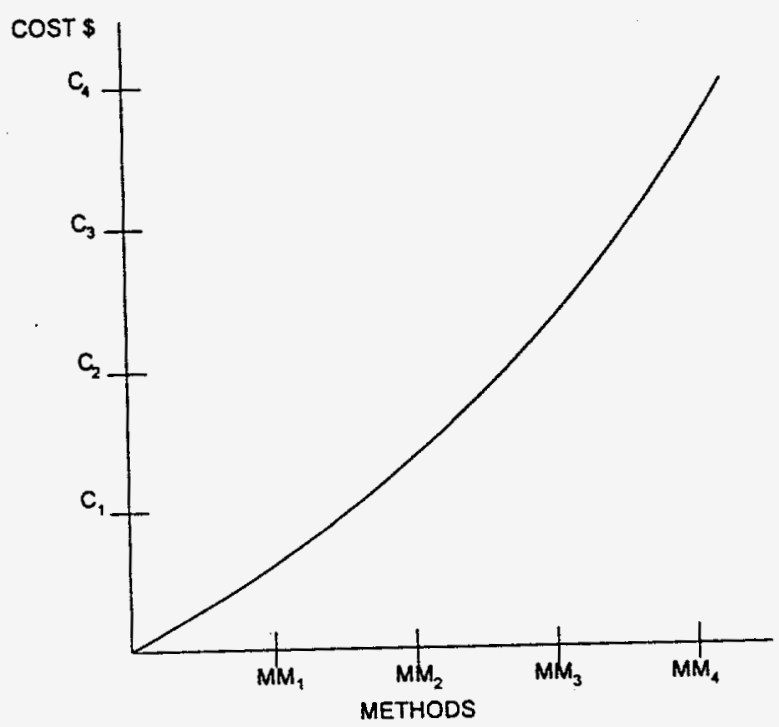

Figure 4.3. The relationship between mitigation method and cost 


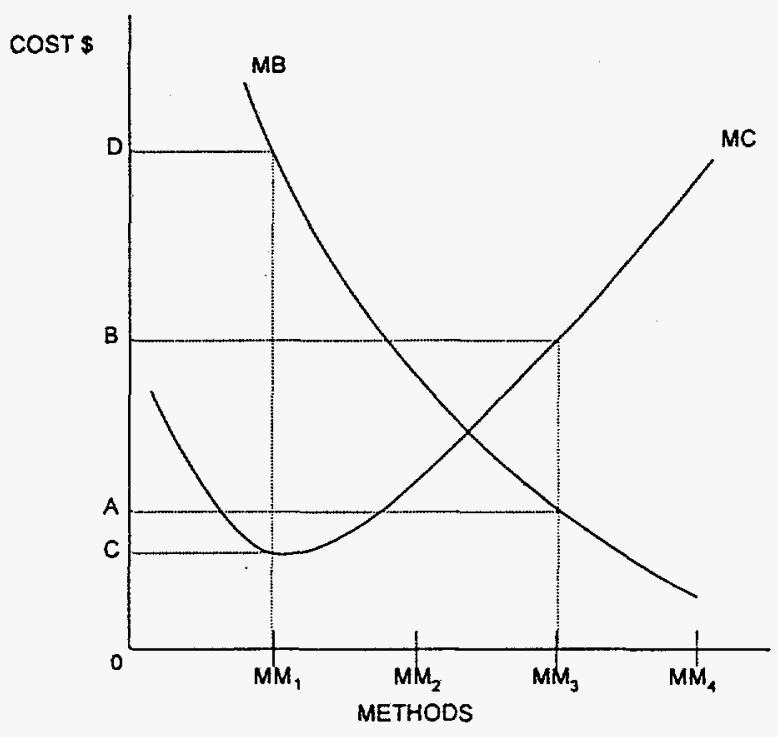

Figure 4.4. Comparison of marginal costs and marginal benefits of mitigation methods and identification of optimal method.

On a practical level, this means that once a commission feels that information risk exceeds the marginal cost of efforts to mitigate that risk, it should turn up its information verification efforts accordingly. In this report, six generic methods or levels of information risk minimization were identified. If the commission currently was at level four, "requiring audits by an independent auditing firm," but felt after doing the above analysis that information risk was increasing and that a net positive benefit cost ratio existed, it would be prudent for the commission to move up to a "level five" effort. Conversely, if the analysis revealed that the marginal costs of the effort exceeded marginal benefits, a commission could be justified in going down at least one level.

Because of the difficulty inherent in quantifying the benefits of information risk mitigation, cost-benefit analysis may be most important as a means of visualizing the mental process required to select the right set of risk-mitigation options. The simple 
lesson from cost-benefit analysis is that the commission should apply additional riskmitigation strategies until the costs of the effort exceed the benefits of the effort. Though "hard data" may not always be available, commissions are skilled at making judgements under conditions of uncertainty and at balancing intangible costs and benefits.

\section{Evaluation of Strategies for Application to Commission Information Needs}

Commission information needs in the near-term future are grouped into five major categories: quality-of-service and customer satisfaction information, market information, utility financial information, social goals information, and affiliate transaction information. ${ }^{5}$ Table 4.1 provides examples of more specific future policy-based commission information needs within those five generic categories.

These information requirements extend across traditional RBROR (as it now exists and will continue to exist for certain segments of the utility industry), the transition to more relaxed forms of regulation, and an environment primarily characterized by price cap, performance-based, or incentive regulation. Over time, traditional commission information needs (e.g., utility financial information) will become less important as the number of utilities under traditional regulation decreases.

${ }^{5}$ Other individual items of information may be required by commissions. These are the five generic groupings of the most important data as identified in the previous chapter of this report. 
TABLE 4.1

EXAMPLES OF FUTURE POLICY-BASED COMMISSION INFORMATION NEEDS

QUALITY-OF-SERVICE AND CUSTOMER-SATISFACTION INFORMATION

- Determining performance standards

- Identifying criteria for resolving service abandonment requests

- Setting bill information standards

- Responding to consumer complaints

- Ensuring universal access

\begin{tabular}{|c|}
\hline $\begin{array}{l}\text { MARKET INFORMATION } \\
\text { - } \text { Determining market penetration } \\
\text { - } \text { Resolving interconnection disputes } \\
\text { - Minimizing market power of incumbent } \\
\text { Reducing barriers to entry and exit }\end{array}$ \\
\hline $\begin{array}{l}\text { UTILITY FINANCIAL INFORMATION } \\
\text { - Obtaining uniform accounting and financial information } \\
\text { - } \text { Assessing validity of depreciation rates } \\
\text { - Resolving stranded investment issues } \\
\text { - } \quad \text { Identifying profitability of regulated entities } \\
\text { - Determining correct regulatory treatment of asset transfers }\end{array}$ \\
\hline $\begin{array}{l}\text { SOCIAL GOALS INFORMATION } \\
\text { - } \quad \text { Responding to needs of disabled customers } \\
\text { - } \quad \text { Ensuring that rural consumers have universal access } \\
\text { - } \quad \text { Assisting consumers regarding source options } \\
\text { other vital social agencies to gain access to the full range of } \\
\text { telecommunication services } \\
\text { - Promoting regional economic development }\end{array}$ \\
\hline $\begin{array}{l}\text { AFFILIATE TRANSACTION INFORMATION } \\
\text { - Evaluating reasonableness of affiliate fees } \\
\text { - Determining correct cost-sharing between regulated and unregulated entities } \\
\text { of utility } \\
\text { - Ascertaining the benefit to consumers of centralized services } \\
\text { - Analyzing executive compensation levels }\end{array}$ \\
\hline
\end{tabular}

Source: Authors' construct. 
Commissions will need to create routines for collecting new information and for reducing the information risk of that information. Some resources may be able to be shifted from traditional utility audits to these new functions. As was mentioned earlier, some commissions have begun to involve staff, including audit staff, in collecting consumer and Over time, traditional commission information needs (e.g., utility financial information) will become less important as the number of utilities under traditional regulation decreases. market information.

As commissions attempt to determine the appropriate level of risk-mitigation option to apply to necessary data, we suggested that they employ a five-step process:

1. Identification of decision-making requirements,

2. Identification of information necessary to support decisions,

3. Evaluation of information risk,

4. Identification of options to mitigate risk,

5. Cost-benefit analysis of the applicable methods for mitigating information risk.

The last three steps will be evaluated in turn for commission information needs.

\section{Evaluation of Information Risk}

In the first chapter of this report, we identified and explained four criteria that increase the level of information risk. They were:

A. The relative importance of the decision that the information is related to.

B. The lack of verifiability of the information.

C. The materiality (quantitative and qualitative) of the information. 
D. The lack of a good working relationship between the information provider and the recipient.

Table 4.2 rates the level of information risk contained in each general category of information required by commissions on a rough, three-point scale (high information risk, moderate information risk, and low information risk) using these criteria. ${ }^{6}$ Because of the close link between importance and materiality, for the purposes of this analysis, the qualitative aspects of materiality were emphasized. As a result, an information category was regarded as having high materiality risk if issues of compliance with commission rules or politically sensitive issues were involved. Because the relationship between state regulatory commissions and information providers is in flux, each

\begin{tabular}{|c|c|c|c|c|}
\hline \multicolumn{5}{|c|}{$\begin{array}{c}\text { TABLE } 4.2 \\
\text { RISK ASSESSMENT FOR COMMISSION INFORMATION NEEDS }\end{array}$} \\
\hline $\begin{array}{l}\text { Type of } \\
\text { Information }\end{array}$ & $\begin{array}{l}\text { A. Decision } \\
\text { Importance }\end{array}$ & $\begin{array}{l}\text { B. Non- } \\
\text { Verifiability }\end{array}$ & C. Materiality & $\begin{array}{l}\text { D. Relationship } \\
\text { between info } \\
\text { provider and } \\
\text { recipient }\end{array}$ \\
\hline $\begin{array}{l}\text { Quality of } \\
\text { Service and } \\
\text { Satisfaction }\end{array}$ & $\mathrm{H}$ & $\mathrm{M}-\mathrm{H}$ & $\mathrm{H}$ & M \\
\hline Market & $\mathrm{H}$ & $\mathrm{M}-\mathrm{H}$ & $M-H$ & M \\
\hline Utility Financial & $M$ & L & L & M \\
\hline Social Goals & L-H & $\mathrm{M}-\mathrm{H}$ & $\mathrm{M}-\mathrm{H}$ & M \\
\hline $\begin{array}{l}\text { Affiliate } \\
\text { Transaction }\end{array}$ & M & $\mathrm{H}$ & M & M \\
\hline \multicolumn{5}{|c|}{$\begin{aligned} & \text { Scale: } \text { H - High Information Risk } \\
& \text { M - Moderate Information Risk } \\
& \text { L - Low Information Risk }\end{aligned}$} \\
\hline
\end{tabular}

${ }^{6}$ These assessments of risk are not identical to but generally parallel the assessments made by the PUCO staff in the exercise cited in Chapter 3. 
category was scored as having a moderate level of risk related to the relationship between the information provider and the recipient. In some cases, a range of values was assigned to attempt to reflect the facts that: (1) elements of information may be more important in some states than in others; (2) in some cases information may be harder to verify given the specific type of information necessary; and (3) in some states, some elements of information may be more material than in others. For example, social goals may be more important in some states than in other states.

While these assessments are less than scientific, some general conclusions can be drawn. Those areas of most importance to future commission decision making in competitive or partially competitive markets are those areas where information has not been traditionally gathered (quality-of-service and market information). Similarly, those areas may contain the hardest to get (and, therefore, to verify) information. Materiality (as defined above) is also highest in those information categories that most directly involve the public (social goals and quality-of-service Those areas of most importance to future commission decision making in competitive or partially competitive markets are those areas where information has not been traditionally gathered (quality-of-service and market information). Similarly, those areas may contain the hardest to get (and, therefore, to verify) information.

information). All other things being equal, regulatory commissions should dedicate proportionately high levels of resources to data collection and risk mitigation in these areas.

\section{Identification of Options to Mitigate Information Risk}

Earlier in this report, we identified the following six illustrative options for mitigation of information risk by commissions: 
1. To require information, but not in any prescribed or standardized format.

2. Requiring standardized financial reports and accounting.

3. Performing desk audits of submitted information.

4. Requiring verification of information by independent auditors.

5. Conducting audits by the commission itself.

6. Independently gathering necessary information.

Of the five general categories of information needed by commissions identified earlier, only one (utility financial information) will likely be provided satisfactorily by the utility. In the other categories, the

The commission will likely become more directly involved in gathering data than it was in the past when the primary means of gathering necessary data was to order the utilities to provide it.

commission will likely become more directly involved in gathering data than it was in the past when the primary means of gathering necessary data was to order the utilities to provide it. In the case of quality-of-service information, commissions may need to employ

surveys of consumers to generate information. As a result of changes in data-collection methods, the full range of risk-mitigation options listed earlier may not be available for some of the categories of information.

The full range of risk-mitigation options is available for utility financial information and, to some extent, for affiliate transaction information, and commission-sponsored audits may be a more useful technique for determining the costs of affiliate transactions than the use of independent auditors. The standard range of options is less applicable where information is not readily available from traditional utility information sources. There are no standardized formats available to the utility or the commission for market information or quality-of-service information and no extensive body of literature related 
to reporting these types of information similar to that available for reporting and auditing financial information. In the case of quality-of-service information, market information, and social goals information, utilityprovided information may provide a starting point or partial information, but in general, commissions will be on their own to gather and interpret the necessary information for decision making.

That is not to say that there are no methodologies available for gathering and analyzing this new information or In the case of quality-of-service information, market information, and social goals information, utility-provided information may provide a starting point or partial information, but in general, commissions will be on their own to gather and interpret the necessary information for decision making. that existing staff have no skills in this area. An extensive body of literature exists in survey research. That literature can help the commission design surveys of its own or evaluate surveys conducted by the utilities. This last requires that at least some commission staff have expertise in survey research techniques.

Though management audits could be employed to evaluate utility efforts to collect customer information, insure compliance with service and safety requirements, and resolve customer complaints, the use of traditional commission-sponsored audits may not be the best technique for mitigating information risk for quality-of-service information and social goals information. Audits may be only partly applicable for mitigating the risk of market information.

\section{Cost-Benefit Analysis of Applicable Methods of Risk-Mitigation}

Having identified the relative level of information risk contained in the information necessary for decision making and the options available for mitigating that risk, the commission can apply some variant of the cost-benefit analysis described at the 
beginning of this chapter to determine which options to use. As indicated above, not all risk-mitigation options are equally applicable to each information category.

As mentioned, public utility commissions should devote the most resources available for information risk mitigation to the areas of highest risk and continue to increase expenditures on risk mitigation until the marginal cost is equal to the marginal benefit. The areas of highest risk are likely to be quality-of-service information and market information. Given the range of options available to mitigate risk in those areas, it may be most appropriate for commissions to independently gather that information. Commissions may also need to look to the development of markets and independently gather market indicators.

This is not to say that it is inappropriate to continue to employ commissionsponsored audits for verifying and discovering information. Audits are appropriate for reducing the information risk inherent in utility financial information and affiliate transaction information. Information risk was defined at the beginning of this report as the possibility that the commission would make an incorrect decision based on faulty information. Enough information risk may still be associated with these types of information to justify audits on a cost-benefit basis. 


\section{CHAPTER 5}

\section{SUMMARY AND CONCLUSIONS}

\section{The Changing Information Needs of State Commissions}

As long as regulatory commissions continue to be required by enabling legislation or constitutional provisions to make decisions, they will require information to support those decisions. In some portions of commission jurisdiction (e.g., water industry regulation), some variant of RBROR regulation will continue to be the norm for the foreseeable future. In these areas, commissions will continue to need much of the same regulatory information that they have used in the past. In transitional markets, regulators will also need to continue to protect those who will not readily be able to reap the full benefits of competition. To protect these In some portions of commission jurisdiction (e.g., water industry regulation), some variant of $R B R O R$ regulation will continue to be the norm for the foreseeable future. In these areas, commissions will continue to need much of the same regulatory information that they have used in the past.

"core customers," regulatory

commissions will still need to gather traditional utility cost and financial information and develop new sources of information to support the transition to competition. These new sources of information will include information on the market impact of utility actions and consumer satisfaction with utility services and consumer preferences for utility services.

Even under a pure price cap model, a regulatory commission will still require cost data in order to reset the base price for the next time period and to ensure that the incremental cost floors established for competitive services and interconnection costs do not result in cross-subsidization or other anti-competitive pricing practices. Because all federal and state price cap plans have been more than the pure price cap model of 
"inflation minus $\mathrm{x}$," regulatory commissions have a statutory or rule-based set of reasons why they need certain cost data. Some of these reasons include, in addition to the important pieces of cost data noted

Even under a pure price cap model, a regulatory commission will still require cost data in order to reset the base price for the next time period and to ensure that the incremental cost floors established for competitive services and interconnection costs do not result in crosssubsidization or other anticompetitive pricing practices. above that exist even under a pure price caps model, determination of costs for profit-sharing or revenue-sharing purposes, inspection of records supporting agreed-upon infrastructure deployment, confirmation of levels of competition needed to trigger new or continued regulatory pricing freedoms, and the need to determine the size and impact of candidate exogenous adjustment requests. ${ }^{1}$

Performance-based and other types of incentive regulation would require intensive use of utility data to discover and construct appropriate indices that might be used to reward or penalize utility performance in a variety of areas, such as power and fuel procurement, quality-of-service, reliability, customer satisfaction, universal service, demand-side management deployment, as well as to pursue other social goals. Without effective discovery and verification of information, performance-based regulation, a potentially valuable tool during the transition from traditional regulation to a more competitive environment, will not be possible.

As utility markets begin to move toward fuller competition, the types of information commissions will need are certain to change. In these markets and under new regulatory regimes, commissions will require new information on consumer satisfaction, utility markets, and social costs. As these information needs emerge,

\footnotetext{
${ }^{1}$ See Raymond Lawton, Edwin Rosenberg, Mary Marvel, and Nancy Zearfoss, Measuring the Impact of Alternative Regulatory Pricing Reforms in Telecommunications (Columbus, Ohio: The National Regulatory Research Institute 1995).
} 
commissions are likely to generate more information directly than before because utilities will not satisfactorily supply all the information needed by commissions.

This is particularly true for some qualityof-service data and most market information.

\section{The Use of Audits}

The fact that commissions need information, however, does not necessarily imply that commissionsponsored audits are required. A variety

Performance-based and other types of incentive regulation would require intensive use of utility data to discover and construct appropriate indices that might be used to reward or penalize utility performance in a variety of areas. Without effective discovery and verification of information, performance-based regulation, a potentially valuable tool during the transition from traditional regulation to a more competitive environment, will not be possible.

of methods exists for reducing information risk. The use of a commission-sponsored audits is only one of those methods.

The decision to use an audit to mitigate information risk should be driven by a cost-benefit analysis of the level of risk inherent in the information and the cost of the risk mitigation options. The goal of a regulatory commission should be to reasonably mitigate information risk using the lowest-cost alternative. Commissions should invest in risk-mitigating techniques until the marginal cost of the effort to mitigate risk exceeds the benefit.

Audits are powerful tools for reducing information risk, and it is likely The goal of a regulatory commission should be to reasonably mitigate information risk using the lowest-cost alternative. Commissions should invest in risk-mitigating techniques until the marginal cost of the effort to mitigate risk exceeds the benefit. that the level of information risk inherent in some information necessary for commission decision making will be high enough to 
justify the continued use of audits. Affiliate transactions, for example, will continue to require evaluation, and audits, focused on the discovery of affiliate transaction information, may be the most effective risk-mitigating tool available to commissions. In traditional and transitional environments, audits will also likely still be warranted. Even in those environments, however, commissions will be challenged to ensure that application of a commission-sponsored audit is the most cost-effective risk-mitigation strategy.

Over time, commission investments in audits may well decrease. As mentioned, new regulatory environments require new sources and types of information.

Commissions will require market

Over time, commission investments in audits may well decrease. It is reasonable to expect that several decisionmaking cycles may be required before commissions can accurately identify the new information risks, let alone develop reliable tools for reducing the risk of inaccurate information. information and quality-of-service information to perform their missions in the new environments. The information risk inherent in those new elements of information, information elements that may be critical to the future missions of regulatory commissions and among the least verifiable pieces of information, may not be able to be reduced cost-effectively by audits. In traditional regulation, it took

decades for commissions to fully understand and resolve the information risk associated with utility data. It is reasonable to expect that several decision-making cycles may be required before commissions can accurately identify the new information risks, let alone develop reliable tools for reducing the risk of inaccurate information.

Commissions should be expected to continue to invest substantial resources in gathering and verifying information, particularly since some of the new information required (e.g., quality-of-service information and market information) cannot satisfactorily be provided by utilities. Whether they perform traditional audits or not, 
current audit staff generally have the basic risk-minimization skills necessary for gathering and verifying these new elements of information.

\section{Commission Access to Proprietary Information}

Unfortunately, the very information that will be increasingly necessary for state and federal utility commissions so that they can play a constructive pro-competitive consumer protection role is the same information that utilities and their competitors are most likely to consider to be confidential or proprietary. State commissions have already heard claims that information is confidential or proprietary in other circumstances where issues have been raised because of new competitive forces being introduced. For example, requests for confidentiality and claims of proprietary information have been raised in the context of licenses and entry in telecommunications services. There, the concern was that real or potential competitors to regulated telecommunications utilities could use the regulatory process to increase the regulated utility's costs, to cause delays

The utility has a legitimate concern that competitors could use the evidentiary process to its competitive disadvantage or even to engage in anti-competitive behavior. On the other hand, state and federal utility commissions and staffs not only need this information to fulfill their new dual role as consumer protectors and protectors of competition--that is, as market referees. or raise barriers of entry, to engage in other anti-competitive behavior by acting as a price follower, or to copy innovations or new service offerings. Similar claims of proprietary information and the need for confidentiality have been raised in fuel and purchased gas adjustment hearings, as well as in the solicitation and evaluation of competitive bids for new power services. In each of these circumstances, the utility has a legitimate concern that competitors could use 
the evidentiary process to its competitive disadvantage or even to engage in anticompetitive behavior.

On the other hand, state and federal utility commissions and staffs not only need this information to fulfill their new dual role as consumer protectors and protectors of competition--that is, as market referees. They also must be concerned with whether the information is necessary to fulfill the requirements of any applicable open records laws and concerned about procedural due process, which in this case concerns the ability of staff, consumer advocates, and other intervenors to cross-examine and rebut or to otherwise check the veracity of the information claimed to be confidential or proprietary. Finally, commissions and their staffs must be concerned about the claim of confidential or proprietary information. Because commission decisions must be based on substantial evidence found within the four-corners of the record, the fundamental issue raised by a claim that information is confidential or proprietary is whether there can be an adequate record upon which to base a decision or to judge an appeal without access to or disclosure of the information.

Commissions may find that claims that information is confidential or proprietary might block a commission from discovering and verifying the kind of information needed for their new role, that is, some or all of the necessary market, quality-of-service, customer service, utility financial, social cost, or affiliated-transaction information might be denied.

There are a number of nonexclusive policy options for state commissions faced with requests for confidentiality and claims of proprietary information. First, commissions and staffs can limit burdensome requests for information, especially "fishing expeditions" for irrelevant and immaterial information. This requires staff members who need information to carefully think through the relevance and materiality of the information to be sought before making an information request and to balance the importance of that information against the cost of supplying the information.

Second, commissioners and their staffs must be cognizant of the potential to misuse information for anti-competitive purposes or to provide an unearned (and unfair) 
competitive advantage to one party or another. To protect against the misuse of market-sensitive information, it is possible to provide information under protective order or under seal with no disclosure to competitors, potential competitors, or the press. Attorneys of the parties, together with their expert witnesses, would be allowed to use and verify the information but would be bound by the protective order not to reveal the information itself to their clients or to the rest of the world. In testimony and orders, references to designated evidence would be by citation To protect against the misuse of market-sensitive information, it is possible to provide information under protective order or under seal with no disclosure to competitors, potential competitors, or the press. and not by quotation. And, the evidence under protective order would be delivered to a reviewing court under seal.

A protective order might be appropriate when dealing with one or more of the following:

(1) materials or documents related to specific customers;

(2) employee-sensitive information;

(3) reports or work papers that comprise the work product for a case;

(4) market analyses or other similar market-sensitive information;

(5) strategies employed, to be employed, or under consideration for contract negotiations;

(6) trade secrets; and

(7) other similar confidential and private technical, financial, and business information.

But before a commission takes the step of placing information under a protective order, it must balance what is good for the development of markets and consumer protection 
with the public interest in open meetings, open hearings, and open records. When commissions consider a request for a protective order, the burden of persuasion is on the party requesting the order.

But before a commission takes the step of placing information under a protective order, it must balance what is good for the development of markets and consumer protection with the public interest in open meetings, open hearings, and open records.
Finally, state commissions could issue a protective order and yet release aggregated information, for example, in the form of an index, without jeopardizing the competitive position of the party or parties submitting the information. In such a case, commission auditors could play a major role in discovering, verifying,

and aggregating the information needed in the new, more competitive environment.

\section{Maintenance of Audit Authority}

No matter which options commissions apply to mitigate information risk, it is prudent that they retain the authority to conduct audits. Generally speaking, to date regulatory commissions have retained

No matter which options commissions apply to mitigate information risk, it is prudent that they retain the authority to conduct audits. their auditing oversight authority and still have access to a wide range of utility financial and cost data, although this authority may be tempered by the desire of commissions to "give relaxed regulation a chance."

In any type of regulatory regime, an information asymmetry will exist such that the regulatory commission will always have less information about the utility than the utility has about itself. In any regime, the goal of a commission should be to have regular and reliable information about key aspects of utility performance and clear authority to get access to any other information required in order for the commission to 
act in or protect the public interest. While the set of "regular and reliable" information needed in a RBROR environment is different than that in a price cap, performancebased, incentive-regulation, or mixed regulatory environment, the need for a commission to have clearly articulated authority to obtain necessary information is quite similar. $^{2}$

Since interested parties are an intrinsic part of any regulatory regime, appropriate information verification tools are needed as long as commissioners are required to make decisions based in whole or in part upon the information submitted by one or more of the parties. Even information submitted by a commission's own staff to its commissioners has been and will continue to be subject to various verification routines by commissioners as they make their decisions or set policy.

\section{Conclusion}

As shown in our brief analysis of other governmental agencies that have deregulated portions of their traditional areas of responsibility, there are many reasonable approaches to minimizing information risk. While it is easier to suggest a cost-benefit analysis than to do one, these other important regulatory agencies have successfully completed some type of analysis and have selected the set of tools that, they believe, best minimizes their information risk.

Obtaining and using accurate information is, and will continue to be, the stock-intrade of public utility regulatory commissions. As a result, commissions will continue to devote substantial resources to gathering information and ensuring its accuracy. In the past, commission-sponsored audits have been an effective means of discovering and

2 Commonly, a photo identification badge is issued to some regulatory commission staff and commissioners that guarantees them immediate access to virtually all utility books and records for verification and other regulatory purposes. It would be fair to say that this badge and the legal authority to use the badge increased the general reliability and validity of the information submitted by a jurisdictional utility. This type of latent or residual authority, even if infrequently used, is a necessary component of effective regulatory oversight. The SEC, for example, seldom directly audits firms, but still has the basic authority to do so if the current system of audit reporting ever broke down. 
verifying information and inducing utilities to comply with commission mandates. In the transition to the new environment, commission auditors will need to work hand-in-hand with strategic policy makers to insure that appropriate provision is made for gathering necessary information and for the continued effective mitigation of information risk. 